\title{
Regional and seasonal feeding by bowhead whales Balaena mysticetus as indicated by stable isotope ratios
}

\author{
Sang Heon Lee ${ }^{1, *}$, Donald M. Schell ${ }^{1}$, Trent L. McDonald ${ }^{2}$, W. John Richardson ${ }^{3}$ \\ ${ }^{1}$ Institute of Marine Science, University of Alaska Fairbanks, 245 O'Neill Building, PO Box 757220, Fairbanks, \\ Alaska 99775-7220, USA \\ ${ }^{2}$ Western EcoSystems Technology Inc., 2003 Central Avenue, Cheyenne, Wyoming 82001, USA \\ ${ }^{3}$ LGL Ltd., environmental research associates, 22 Fisher Street, POB 280, King City, Ontario L7B 1A6, Canada
}

\begin{abstract}
The feeding habitats of the Bering-Chukchi-Beaufort stock of bowhead whales Balaena mysticetus during summer and fall migration are generally known, but the relative amounts of food they consume in various parts of the seasonal range are poorly understood. We used natural geographic gradients in stable isotope ratios of carbon and nitrogen within zooplankton (bowhead prey) to measure the relative importance of the eastern Beaufort Sea versus Bering and Chukchi Seas (combined) as feeding habitat for bowheads. The $\delta^{13} \mathrm{C}$ content of their prey differs by $3.9 \%$, on a weighted average basis, between the 2 regions. $\delta^{13} \mathrm{C}$ in bowhead muscle changed by only $0.5 \%$ while bowheads were in the Beaufort Sea, indicating that only ca. $10 \%$ of the muscle carbon in the average whale turns over during summer feeding, with $95 \%$ confidence intervals (CI) of 0 to $23 \%$. Considering subadult whales only, estimated turnover averaged $14 \%$ with $95 \%$ CI of 4 to $23 \%$. For adults, the estimated turnover was $5 \%(95 \% \mathrm{CI}=0$ to $30 \%)$. Overall $\delta^{13} \mathrm{C}$ values in muscle are not significantly different in adult and subadult bowheads, suggesting no major age-related shift in the relative importance of different feeding habitats, and very closely matching Bering-Chukchi-derived food. $\delta^{15} \mathrm{~N}$ values for muscles were near $1 \%$ higher in whales taken in the $1980 \mathrm{~s}$, consistent with the observed long-term declining trends in environmental $\delta^{15} \mathrm{~N}$ values as indicated by chronological sampling of baleen plates. In contrast to muscle data, $\delta^{13} \mathrm{C}$ values in baleen, each representing feeding during a shorter time increment, do show seasonal and age-related differences. Subadult whales apparently feed more in the eastern Beaufort Sea than do adults, but nonetheless acquire insufficient food there to significantly alter their bulk carbon isotope ratios.
\end{abstract}

KEY WORDS: Feeding habitats $\cdot$ Bowhead whales $\cdot$ Balaena mysticetus $\cdot$ Migration $\cdot$ Diet $\cdot$ Trophics Zooplankton $\cdot$ Stable isotopes $\cdot \delta^{13} \mathrm{C} \cdot \delta^{15} \mathrm{~N} \cdot$ Beaufort Sea $\cdot$ Bering Sea $\cdot$ Chukchi Sea

\section{INTRODUCTION}

The bowhead whale Balaena mysticetus is a large baleen whale that was historically abundant in northern circumpolar waters. Commercial whaling over 3 centuries reduced the numbers in the Atlantic Ocean to small remnants (Ross 1993). The Pacific populations were also reduced to small fractions of their original numbers (Bockstoce \& Burns 1993). The largest remaining stock is the Bering-Chukchi-Beaufort stock, which numbered about 10470 individuals in 2001, and is increasing at about $3.4 \%$ per year (George et al. 2004). This population overwinters in the sea ice of the northern Bering Sea and then moves northeastward in the spring, entering the Beaufort Sea in April to June. Much of the population is in the eastern Beaufort Sea from June throughout the summer, with most individuals departing westward in September and 


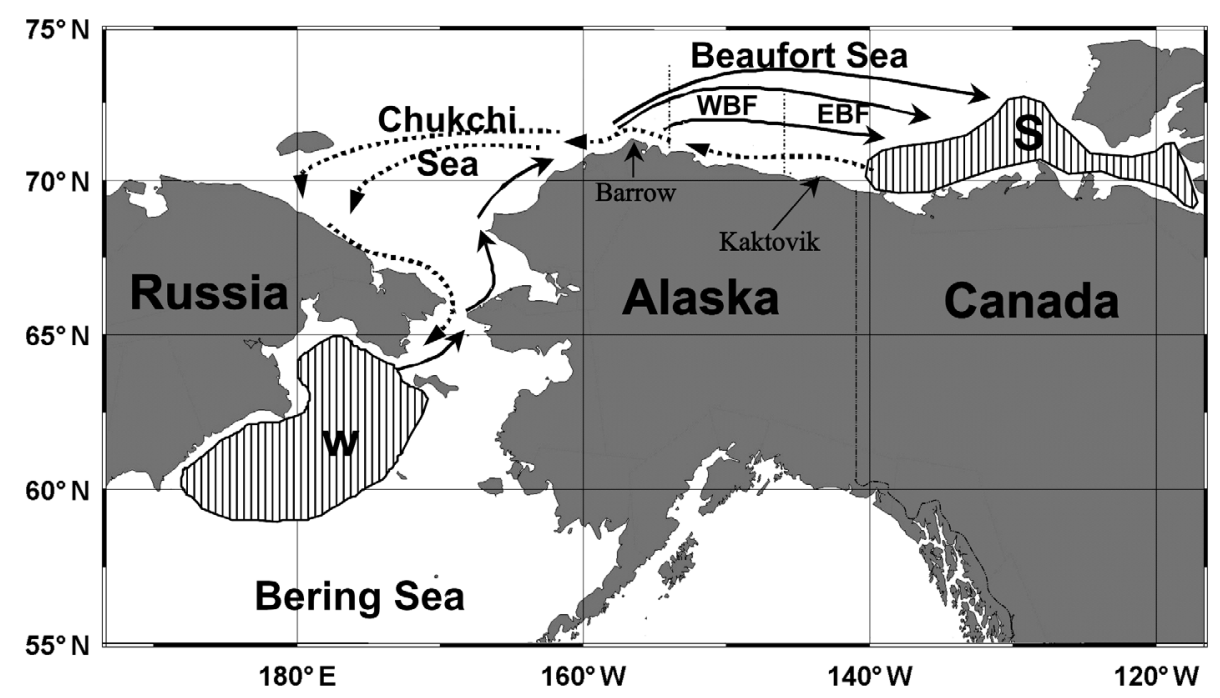

Fig. 1. Balaena mysticetus. Migration routes of bowhead whales of the Bering-Chukchi-Beaufort stock (from Schell et al. 1989). S: summering ground; W: wintering ground; WBF: western Beaufort Sea; EBF: eastern Beaufort Sea

early October (Moore \& Reeves 1993 and present Fig. 1). The whales return to the Bering Sea by way of northern Alaska and (in at least some cases) NE Russia. Feeding has been observed in the Canadian Beaufort Sea in summer and in both the Alaskan Beaufort Sea and near the Russian coast of the Chukchi Sea during autumn. Over the past 3 decades, offshore oil exploration and (more recently) development have occurred in some parts of the summer and autumn range in the Canadian and Alaskan Beaufort Sea (Richardson et al. 1987).

The feeding habitats of the whales during the summer and the fall migration are generally known, but the relative amounts of food consumed from various parts of the seasonal range are poorly understood. This study attempts to quantify the relative importance of the eastern Beaufort Sea (eastern Alaskan plus Canadian Beaufort Seas) as a feeding habitat for the Bering-Chukchi-Beaufort stock of bowhead whales. It also compares feeding strategies of subadult and adult bowheads.

Various methods can provide information about feeding habitats and amounts of food consumed by populations of whales, including observations of feeding behavior, stomach contents, energy reserves during different seasons, and stable isotopes. Each method provides a limited perspective, but the results from different methods are often complementary: (1) Behavioral observations can show the manner and location of feeding, and how much time is devoted to feeding, but yield little information as to how much food a whale consumes in a given location. Feeding behavior is at times difficult to detect or to distinguish from other behavior, especially when it occurs far below the surface or in extensively ice-covered areas. However, Würsig et al. $(1985,1989)$ and Würsig \& Clark (1993) have provided fairly detailed descriptions of feeding behavior as observed in the Beaufort Sea. (2) Stomach content analysis shows whether feeding has occurred recently, what a whale has most recently eaten, and what quantity is present in the stomach. These estimates can be compared for whales examined in specific regions and seasons (Lowry 1993, Lowry et al. in press). However, this method represents only the feeding that occurred close to the sampling site(s) during a short interval of time prior to sampling (Hobson \& Clark 1992, Hobson et al. 1996). It is also complicated when there is significant delay between the time the whale is killed and the time when the stomach contents can be sampled. (3) Energy reserves as measured by blubber thickness or other parameters during different seasons have provided data on seasonal feeding in other baleen whales (e.g. Lockyer 1981, Víkingsson 1990), and are now being applied to the bowhead whale.

Stable isotope ratios provide another approach that can help identify important feeding habitats for migratory animals (Fry 1981, Schell 1987, Schell et al. 1989). Animals acquire a natural isotopic tag from their diet (Fry 1981). If the stable isotope ratios in the food are sufficiently different in specific parts of the annual range in which feeding occurs, and if these differences are transferred conservatively and predictably to the animals, the relative importance of the different feeding areas can be determined (Schell \& Saupe 1993).

Schell et al. (1989) reported annual oscillations of $\delta^{13} \mathrm{C}$ and $\delta^{15} \mathrm{~N}$ along the length of bowhead baleen plates. These oscillations, along with seasonal changes 
in isotopic composition of muscle, apparently resulted from annual migrations of the whales from summering grounds in the eastern Beaufort Sea (where food sources are relatively depleted in ${ }^{13} \mathrm{C}$ ) to late-autumn feeding areas and wintering grounds in the Chukchi and Bering seas (where the food contains relatively more ${ }^{13} \mathrm{C}$ ). Previous studies of isotopic composition of bowheads have provided new insight into their feeding habitats in a remote area (Schell \& Saupe 1993). The isotope results of Schell \& Saupe (1993), combined with data on seasonal and geographic patterns in zooplankton production, suggested that most annual feeding occurs in late summer and fall during the return migration from the western Beaufort Sea through the Chukchi Sea and into the Bering Sea. The large concentrations of zooplankton that mature over the summer in the northern Bering Sea are carried northward by the Anadyr current through the Bering Strait (Springer et al. 1989) into the Chukchi Sea, and have been observed being preyed upon by the returning whales (Moore et al. 1995).

Increased interest in the eastern Alaskan Arctic, along with continued questions about relative amounts of feeding by bowheads in the eastern Beaufort vs. Bering-Chukchi systems, has led to a detailed reexamination of feeding scenarios for these whales. Our primary objective was to use stable isotope methods to assess the relative amounts of feeding in the eastern Beaufort Sea vs. the Bering and Chukchi (combined) Seas, including a comparison of feeding strategies by adult vs. subadult bowhead whales. Also, we were interested in comparing feeding strategies in recent vs. earlier years. Recent evidence that the productivity of the Bering and Chukchi Seas may have declined suggested that feeding in the eastern Beaufort Sea might be more important to bowhead whales now than in previous decades (Schell 2000, 2001). As in earlier related studies, our approach was based on the fact that samples of bowhead tissues can be obtained in northern Alaska during the spring and autumn migrations, when bowhead whales are harvested by Inupiat hunters (Stoker \& Krupnik 1993).

In addition, a recent paper by Hoekstra et al. (2002) using similar isotopic techniques indicated that bowhead whale feeding in the eastern Beaufort Sea is important in the annual food budget for these animals. The conclusions reached by Hoekstra et al. (2002) differ from ours and are discussed in detail in the second subsection of 'Discussion'.

\section{MATERIALS AND METHODS}

Sample preparation for stable isotope analysis. We obtained one of the longest baleen plates from 4 of the whales killed at Barrow and all 10 whales landed at Kaktovik during 1997 to 1999; of these, 13 were killed in autumn (Table 1). Additional comparative data were obtained from baleen collected in past studies during both spring (predominantly) and autumn (1986 to 1988: Table 1). From 0 to $100 \mathrm{~cm}$ from the proximal end, samples were taken at $1 \mathrm{~cm}$ intervals using a flexible-shaft engraving tool. Beyond $100 \mathrm{~cm}$, plates were sampled at $2 \mathrm{~cm}$ intervals. As an example, the ${ }^{13} \mathrm{C}$ data obtained from Whale $97 \mathrm{KK} 2$ (the 2nd whale landed at Kaktovik in 1997) are shown in Fig. 2.

Muscle samples were obtained from 14 whales harvested at Barrow and the 10 whales harvested at Kaktovik during the autumns of 1997 to 1999. Approximately $5 \mathrm{~g}$ of muscle was collected from each whale by personnel from the Alaska Department of Fish \& Game or the North Slope Borough Department of Wildlife Management. Subsamples were dried at $65^{\circ} \mathrm{C}$ for $2 \mathrm{~d}$ to constant weight. Muscle samples from 25 additional whales taken in 1986 to 1988, mainly in spring, were used in comparisons (see Table 5). Lipid in the muscle was not extracted during either period. For proteinaceous samples, the focus of this study, lipid effects were largely avoided, as many amino acids are essential and derived intact from diet.

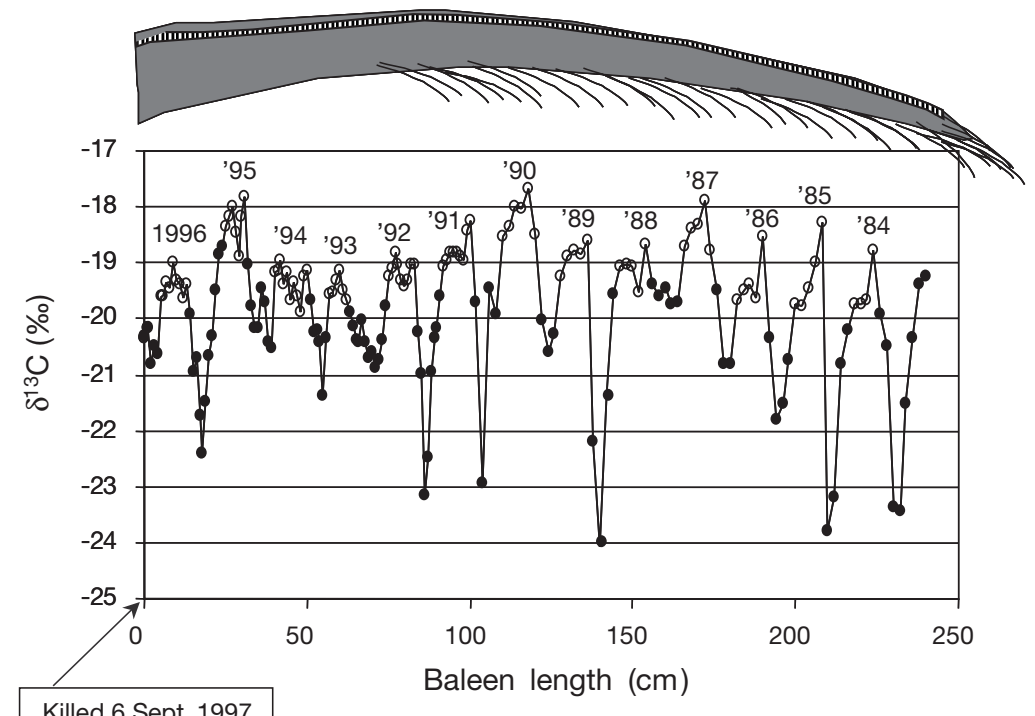

Killed 6 Sept. 1997

Fig. 2. Balaena mysticetus. Carbon isotope ratios along a baleen plate from Bowhead Whale 97KK2, a 13.2 m male taken at Kaktovik, Alaska, on 6 September 1997. Each oscillation = 1 yr growth; the most recently formed baleen is on left. (O) assumed to indicate feeding on Bering-Chukchi prey; (•) assumed to indicate contribution of Beaufort Sea carbon 
Table 1. Balaena mysticetus. Bowhead whale samples collected during 1997 to 1999 (this study) and 1986-1988 (Schell 1992). Baleen samples were obtained from whales for which baleen length is listed; muscle samples were obtained from all listed whales except for 97B8, 97B11 and 97B12. -: no data

\begin{tabular}{|c|c|c|c|c|c|c|}
\hline Whale & Date landed & Village & $\begin{array}{l}\text { Whale } \\
\text { length }(\mathrm{m})\end{array}$ & $\begin{array}{l}\text { Baleen } \\
\text { length (m) }\end{array}$ & Sex & Age class \\
\hline \multicolumn{7}{|c|}{ 1997-1999 } \\
\hline 97B8 & 15 May 1997 & Barrow & 13.6 & 2.54 & $\mathrm{~F}$ & Adult \\
\hline 97B11 & 11 Sep 1997 & Barrow & 13.6 & 3.00 & M & Adult \\
\hline 97B12 & 12 Sep 1997 & Barrow & 15.3 & 3.12 & M & Adult \\
\hline 97B14 & 20 Sep 1997 & Barrow & 8.6 & - & $\mathrm{F}$ & Subadult \\
\hline 97B16 & 20 Sep 1997 & Barrow & 8.3 & - & $\mathrm{F}$ & Subadult \\
\hline 97B18 & 22 Sep 1997 & Barrow & 10.8 & - & $\mathrm{M}$ & Subadult \\
\hline $97 \mathrm{~B} 20$ & 26 Sep 1997 & Barrow & 8.6 & - & $\mathrm{M}$ & Subadult \\
\hline 97B21 & 27 Sep 1997 & Barrow & 9.2 & - & $\mathrm{F}$ & Subadult \\
\hline 97B22 & 27 Sep 1997 & Barrow & 9.4 & - & $\mathrm{F}$ & Subadult \\
\hline 97B23 & 27 Sep 1997 & Barrow & 10.3 & - & $\mathrm{M}$ & Subadult \\
\hline 97B24 & 28 Sep 1997 & Barrow & 8.6 & - & $\mathrm{F}$ & Subadult \\
\hline 97B25 & 28 Sep 1997 & Barrow & 11.7 & 2.08 & M & Subadult \\
\hline $97 \mathrm{~B} 26$ & 29 Sep 1997 & Barrow & 13.5 & - & $\mathrm{M}$ & Adult \\
\hline $97 \mathrm{~B} 27$ & 2 Oct 1997 & Barrow & 9.5 & - & M & Subadult \\
\hline 97B28 & 2 Oct 1997 & Barrow & 8.4 & - & $\mathrm{M}$ & Subadult \\
\hline 97B29 & 17 Oct 1997 & Barrow & 8.5 & - & $\mathrm{M}$ & Subadult \\
\hline 97B30 & 18 Oct 1997 & Barrow & 8.0 & - & $\mathrm{F}$ & Subadult \\
\hline 97KK1 & 3 Sep 1997 & Kaktovik & 8.7 & 1.50 & $\mathrm{~F}$ & Subadult \\
\hline $97 \mathrm{KK} 2$ & 6 Sep 1997 & Kaktovik & 13.2 & 2.50 & $\mathrm{M}$ & Subadult \\
\hline 97KK3 & 11 Sep 1997 & Kaktovik & 8.3 & 1.32 & $\mathrm{~F}$ & Subadult \\
\hline 97KK4 & 27 Sep 1997 & Kaktovik & 14.6 & 3.06 & $\mathrm{M}$ & Adult \\
\hline 98KK1 & 4 Sep 1998 & Kaktovik & 10.4 & 1.92 & M & Subadult \\
\hline 98KK2 & 10 Sep 1998 & Kaktovik & 8.9 & 1.44 & $\mathrm{~F}$ & Subadult \\
\hline 98KK3 & 14 Sep 1998 & Kaktovik & 9.2 & 1.70 & M & Subadult \\
\hline 99KK1 & 11 Sep 99 & Kaktovik & 7.7 & 0.86 & $\mathrm{~F}$ & Subadult \\
\hline 99KK2 & 12 Sep 99 & Kaktovik & 12.9 & 2.44 & M & Subadult \\
\hline 99KK3 & 16 Sep 99 & Kaktovik & 8.3 & 1.32 & $\mathrm{M}$ & Subadult \\
\hline \multicolumn{7}{|c|}{ 1986-1988 } \\
\hline 86B1 & 27 Apr 1986 & Barrow & 8.2 & - & $\mathrm{M}$ & Subadult \\
\hline 86B2 & 27 Apr 1986 & Barrow & 8.7 & - & M & Subadult \\
\hline 86B3 & 3 Apr 1986 & Barrow & 8.9 & 1.60 & $\mathrm{~F}$ & Subadult \\
\hline 86B4 & 1 May 1986 & Barrow & 8.9 & 1.30 & $\mathrm{M}$ & Subadult \\
\hline 86B5 & 4 May 1986 & Barrow & 8.1 & 0.85 & M & Subadult \\
\hline $86 B 6$ & 5 May 1986 & Barrow & 12.3 & - & $\mathrm{F}$ & Subadult \\
\hline 86B7 & 6 May 1986 & Barrow & 10.7 & 2.01 & M & Subadult \\
\hline 86KK1 & 10 Sep 1986 & Kaktovik & 7.6 & - & $\mathrm{F}$ & Subadult \\
\hline 86KK2 & 17 Sep 1986 & Kaktovik & 17.1 & 3.80 & $\mathrm{~F}$ & Adult \\
\hline 86KK3 & 26 Sep 1986 & Kaktovik & 10.4 & 1.85 & M & Subadult \\
\hline 86WW1 & 5 May 1986 & Wainwright & 15.9 & 2.69 & M & Adult \\
\hline 86WW2 & 10 May 1986 & Wainwright & 17.7 & 3.10 & $\mathrm{~F}$ & Adult \\
\hline 87B1 & 1 May 1987 & Barrow & 9.3 & 1.68 & M & Subadult \\
\hline 87B2 & 2 May 1987 & Barrow & 8.9 & 1.50 & $\mathrm{~F}$ & Subadult \\
\hline 87B3-A & 4 May 1987 & Barrow & 11.0 & 1.95 & $\mathrm{M}$ & Subadult \\
\hline 87B4 & 2 May 1987 & Barrow & 16.8 & 2.95 & $\mathrm{~F}$ & Adult \\
\hline 87B5 & 15 Jun 1987 & Barrow & 15.7 & 3.00 & $\mathrm{~F}$ & Adult \\
\hline 87B6 & 22 Oct 1987 & Barrow & 15.7 & 3.15 & $\mathrm{~F}$ & Adult \\
\hline $87 \mathrm{~B} 7$ & 29 Oct 1987 & Barrow & 8.5 & - & M & Subadult \\
\hline $87 \mathrm{G} 2$ & 24 Apr 1987 & Gambell & 16.8 & 3.45 & $\mathrm{~F}$ & Adult \\
\hline $87 \mathrm{~N} 1$ & 5 Oct 1987 & Nuiqsut & 15.2 & 3.30 & $\mathrm{~F}$ & Adult \\
\hline 87WW2 & 8 May 1987 & Wainwright & 13.5 & 2.15 & $\mathrm{M}$ & Adult \\
\hline 88B1 & 24 Apr 1988 & Barrow & 8.9 & 0.98 & M & Subadult \\
\hline 88B2 & 25 Apr 1988 & Barrow & 8.8 & - & M & Subadult \\
\hline 88B3 & 25 Apr 1988 & Barrow & 7.8 & - & $\mathrm{F}$ & Subadult \\
\hline 88B4 & 25 Apr 1988 & Barrow & 9.0 & - & $\mathrm{F}$ & Subadult \\
\hline 88B5 & 25 Apr 1988 & Barrow & 8.9 & - & $\mathrm{M}$ & Subadult \\
\hline 88B6 & 2 May 1988 & Barrow & 8.4 & - & $\mathrm{F}$ & Subadult \\
\hline 88B7 & 5 May 1988 & Barrow & 8.2 & - & $\mathrm{F}$ & Subadult \\
\hline 88B8 & 6 May 1988 & Barrow & 7.5 & - & $\mathrm{F}$ & Subadult \\
\hline 88B9 & 15 Sep 1988 & Barrow & 14.6 & 2.57 & $\mathrm{M}$ & Adult \\
\hline 88B10 & 17 Sep 1988 & Barrow & 15.1 & 3.02 & $\mathrm{M}$ & Adult \\
\hline $88 \mathrm{G} 2$ & 25 Apr 1988 & Gambell & 15.3 & - & $\mathrm{F}$ & Adult \\
\hline 88KK1 & 24 Sep 1988 & Kaktovik & 14.9 & 2.97 & $\mathrm{~F}$ & Adult \\
\hline
\end{tabular}


The finely powdered baleen and muscle were weighed into cups ( 0.8 to $1.0 \mathrm{mg}$ ) and the isotope ratios analyzed using a Europa continuous-flow isotope-ratio mass spectrometer. All $\delta^{13} \mathrm{C}$ and $\delta^{15} \mathrm{~N}$ isotope values are reported against, respectively, PDB and air standards as $\delta^{13} \mathrm{C}_{\mathrm{PDB}}(\%)$ or $\delta^{15} \mathrm{~N}_{\text {air }}(\%)$ :

$$
\delta=\frac{R_{\text {sample }}-R_{\text {standard }}}{R_{\text {standard }}} \times 1000
$$

where $R$ is the ratio ${ }^{13} \mathrm{C}:{ }^{12} \mathrm{C}$ or ${ }^{15} \mathrm{~N}:{ }^{14} \mathrm{~N}$.

Use of $\boldsymbol{\delta}^{\mathbf{1 3}} \mathbf{C}$ to assess feeding. To estimate feeding activity in regions represented by the isotope ratios along the baleen plates, approximate dietary composition (Table 2) and stable isotope values for various components of the diet (Table 3) were defined for the eastern Beaufort and for the Bering + Chukchi regions. Because average isotope ratios of prey from these areas are quite distinct, and because these regions are the geographic extremes of the range of this bowhead population, these 2 regions were used as end members. Zooplankton from the central and western Beaufort Sea has intermediate $\delta^{13} \mathrm{C}$ values (Saupe et al. 1989). Active feeding has been observed in the western Beaufort Sea during autumn in some years (e.g. Lowry 1993, Landino et al. 1994, Treacy 2002). However, this feeding is probably on Chukchi Sea zooplankton advected into the western Beaufort Sea. Some water from the Bering Sea is advected north through Bering Strait and the Chukchi Sea, and enters the western Beaufort (Aagaard 1984).

Table 2. Balaena mysticetus. Approximate composition (\%) of the bowhead whale diet (updated from Lowry et al. in press)

\begin{tabular}{|lcc|}
\hline Item & Eastern Beaufort $^{\mathrm{a}}$ & Bering $^{+ \text {Chukchi }^{\mathrm{b}}}$ \\
\hline Copepods & 61 & 28 \\
Euphausiids & 22 & 61 \\
Mysids & 6 & 1 \\
Amphipods & 5 & 4 \\
${ }^{\text {aBBased on stomach contents at Kaktovik in fall }}$ \\
'based on stomach contents at Barrow in spring \\
\hline
\end{tabular}

Table 3. Approximate average values of $\delta^{13} \mathrm{C}$ and $\delta^{15} \mathrm{~N}(\%)$ for main prey taxa from 1985 and 1994, calculated from Schell et al. (1998) and Schell (1992). -: no data

\begin{tabular}{|lcccc|}
\hline \multirow{2}{*}{ Item } & \multicolumn{3}{c}{ Eastern Beaufort } & \multicolumn{2}{c|}{$\begin{array}{c}\text { Bering } \\
\end{array}$} & \multicolumn{2}{c}{ Chukchi } \\
& $\delta^{13} \mathrm{C}$ & $\delta^{15} \mathrm{~N}$ & $\delta^{13} \mathrm{C}$ & $\delta^{15} \mathrm{~N}$ \\
\hline Copepods & -25.6 & 10.4 & -22.2 & 10.5 \\
Euphausiids & -23.7 & 9.2 & -20.8 & 10.13 \\
Mysids & -23.6 & 8.5 & - & - \\
Amphipods & -23.9 & 8.2 & - & - \\
\hline
\end{tabular}

Specific data on diet composition are available only from locations where bowhead whales were harvested and their stomach contents examined. The stomach contents of bowheads harvested at Kaktovik in September provide data on diet composition in that area and season. Most of the Kaktovik-harvested whales had fed recently (Lowry et al. in press). Use of these data to represent dietary proportions throughout the eastern Beaufort Sea in summer is subject to uncertainty about local and temporal variations, differential digestion, etc. However, net tow-data from Saupe et al. (1989) and other sources indicate that the zooplankton of the eastern Beaufort Sea is dominated by calanoid copepods with few euphausiids, generally consistent with the prey in the bowhead stomachs examined at Kaktovik. The reverse is true for bowheads harvested near Barrow, where euphausiids have dominated the stomach contents in fall and (in recent years) spring (Lowry 1993, Lowry et al. in press). It is uncertain how representative this is of the overall composition of the bowhead diet in the Bering-Chukchi diet region (including western Beaufort waters).

The tendency for $\delta^{13} \mathrm{C}$ values in copepods to be lower than those in euphausiids (difference of $\sim 1.9 \%$ ), combined with the greater contribution of copepods to the diet in the eastern Beaufort Sea, increases the overall isotopic gradient in the available food and in the diet across the migratory range. If the diet were entirely euphausiids when in the Bering-Chukchi region, and entirely copepods in the eastern Beaufort, the geographic and seasonal shift in the carbon isotope ratio in the diet would be $\sim 4.8 \%$. With the opposite scenario of all copepods in the Bering-Chukchi and all euphausiids in the eastern Beaufort Sea, the difference would be only $1.5 \%$. Net tow-data on zooplankton abundance (Saupe et al. 1989) and stomach-content data on bowhead diet at Kaktovik and Barrow (Lowry et al. in press) both suggest that the former scenario is much closer to reality. Nevertheless, the relative abundances of prey taxa may change substantially from year to year across the range. Whether the whales target specific taxa preferentially, as opposed to feeding on the most abundant available taxon, is also unknown.

Data on isotope ratios in zooplankton from different parts of the bowhead range are the result of many years of sampling in many locations. The areas of most intense coverage are the eastern Beaufort Sea in both nearshore and offshore waters, and the Bering Sea. Sampling coverage is shown in Schell et al. (1998), and additional samples were taken in the eastern Alaskan Beaufort Sea during the present study (Table 4). Observed geographic patterns in isotope ratios have remained consistent across the years.

Anticipated $\delta^{13} \mathrm{C}$ and $\delta^{15} \mathrm{~N}$ values for the total consumed prey from each end-member region were deter- 
Table 4. Average zooplankton isotope ratios $( \pm \mathrm{SD} ; \mathrm{n}=$ number of samples) for the eastern Alaskan Beaufort Sea in 1998 and 1999 (this study), compared with data of Schell et al. (1998) for the eastern Beaufort Sea as a whole

\begin{tabular}{|lccrrrr|}
\hline & $\delta^{13} \mathrm{C}$ & $\mathrm{SD}$ & $\mathrm{n}$ & $\delta^{15} \mathrm{~N}$ & $\mathrm{SD}$ & $\mathrm{n}$ \\
\hline $\mathbf{1 9 9 9}$ & & & & & & \\
Copepods & -25.6 & 0.59 & 33 & 10.3 & 0.56 & 33 \\
Euphausiids & -24.2 & 0.85 & 5 & 11.0 & 0.29 & 5 \\
Chaetognaths & -23.5 & 0.18 & 4 & 12.3 & 0.75 & 4 \\
$\mathbf{1 9 9 8}$ & & & & & & \\
Copepods & -24.7 & 0.37 & 30 & 10.8 & 0.99 & 30 \\
Euphausiids & -23.1 & 1.18 & 5 & 11.2 & 0.71 & 5 \\
Chaetognaths & -23.2 & 0.32 & 11 & 12.8 & 0.81 & 11 \\
Schell et al. (1998) & & & & & \\
Copepods & -25.7 & 0.20 & 57 & 10.8 & 0.19 & 45 \\
Euphausiids & -23.7 & 0.32 & 21 & 9.2 & 0.57 & 18 \\
Chaetognaths & -23.4 & 0.33 & 5 & 13.5 & 0.60 & 5 \\
\hline
\end{tabular}

mined by calculating a weighted average of the taxon $\delta^{13} \mathrm{C}$ values from Table 3, using dietary proportions from Table 2 as weighting factors. We considered only copepods and euphausiids, the dominant zooplankton and dominant prey items (Saupe et al. 1989, Lowry 1993, Lowry et al. in press). For the eastern Beaufort Sea,

$\delta^{13} \mathrm{C}=$ (average $\delta^{13} \mathrm{C}$ of copepods $\times$ proportion of copepods in bowhead diets) + (average $\delta^{13} \mathrm{C}$ of euphausiids $\times$ proportion of euphausiids), i.e. $[(-25.6)(61 \%)+(-23.7)(22 \%)] /(83 \%)=-25.1 \%$;

$\delta^{15} \mathrm{~N}=10.1 \%$, based on a calculation parallel to the above.

In the Bering and Chukchi Seas, $\delta^{13} \mathrm{C}=-21.2 \%$, and $\delta^{15} \mathrm{~N}=10.2 \%$.

These values are the anticipated average isotopic composition of the prey consumed in each region. The difference in $\delta^{13} \mathrm{C}$ between the assumed diets during summer and early autumn in the eastern Beaufort Sea as compared with late autumn and winter in Bering-Chukchi waters, including the western Beaufort, is $3.9 \%$. The eastern Beaufort Sea could not be further divided into Alaskan and Canadian sectors due to the lack of significant differences in $\delta^{13} \mathrm{C}$ and $\delta^{15} \mathrm{~N}$ values for zooplankton from these 2 sectors (Schell et al. 1998). Hence, the eastern Beaufort Sea end member includes both sectors. For simple mixing models, use of $\delta^{13} \mathrm{C}$ is more practical than $\delta^{15} \mathrm{~N}$ because a much larger gradient in $\delta^{13} \mathrm{C}$ is present in progressing from the Bering and Chukchi Seas to the eastern Beaufort region.

The $\delta^{13} \mathrm{C}$ values at locations 0 to $50 \mathrm{~cm}$ from the basal end of the baleen, representing the most recent 2 or $3 \mathrm{yr}$ of baleen growth, were used as a measure of the duration of feeding in each isotopic regime. The baleen growth rate is 16 to $25 \mathrm{~cm} \mathrm{yr}^{-1}$ (Schell \& Saupe
1993), and baleen is assumed to grow at a constant rate whether the whales are actively feeding or not. Comparison of plates from whales taken in spring and fall showed similar growth rates during summer and winter (Schell et al. 1989). It is also assumed that baleen reflects the immediate diet during periods of active feeding and average body protein composition during periods of fasting (Best \& Schell 1996). In the latter case, overall baleen isotope ratios would tend to reflect primary food sources year-round and show only small seasonal shifts if the whales moved into regions of differing prey isotope ratios where they did not acquire significant quantities of food. Many adult bowhead whales exhibit this type of isotopic trace.

The intermediate $\delta^{13} \mathrm{C}$ values between -18.8 and $-22.0 \%$ evident in parts of the baleen are assumed to arise when the whale moves from one isotopic regime into the other (Bering-Chukchi vs. eastern Beaufort) during migration. Shifts in isotope ratios along the baleen indicate that feeding was occurring as the baleen was deposited, but do not give quantitative information as to the amount of food consumed. However, the amplitude of the annual isotopic cycle provides some information. It is reasonable to assume that large amplitudes in isotopic ratios reflect substantial feeding from each of the 2 regimes, whereas a small amplitude (combined with an isotopic value characteristic of one region) implies that most food was from that region. This interpretation also requires the assumption that the zooplankton in the 2 regions retains the same difference in isotope ratios from year to year. As such, the baleen isotopic data are useful only as a relative indicator of feeding activity, and when comparing whales taken during periods with little year-to-year change in isotope ratios.

Correction for changing $\delta^{13} \mathrm{C}$ and $\delta^{15} \mathrm{~N}$ in Bering and Chukchi s eas biota. An additional correction is also needed in using our data on isotope ratios to assess regional feeding. Carbon isotope ratios in parts of the baleen laid down in the Bering and Chukchi Seas have shown an overall decrease, over the $11 \mathrm{yr}$ period from 1983-1987 to 1994-1998, of about $0.7 \%$. This is based on the $0.0627 \% \mathrm{yr}^{-1}$ trend found by Schell (2000, 2001; see present Fig. 3). For both carbon and nitrogen, there has been a pronounced decline in isotope ratios in the baleen laid down over the past several decades, presumably representing a corresponding decline in the isotope ratios in the prey in the Bering-Chukchi system. The average $\delta^{13} \mathrm{C}$ decreased by $\sim 2.7 \%$ from 1965 to 1998 . The average $\delta^{15} \mathrm{~N}$ decreased by about 1.3\% from 1953 to 1998. This decline has been ascribed to a progressive decline in primary productivity in the Bering Sea, although other mechanisms may be contributing (see Schell 2000, 2001, also comment by Cullen et al. 2001). 


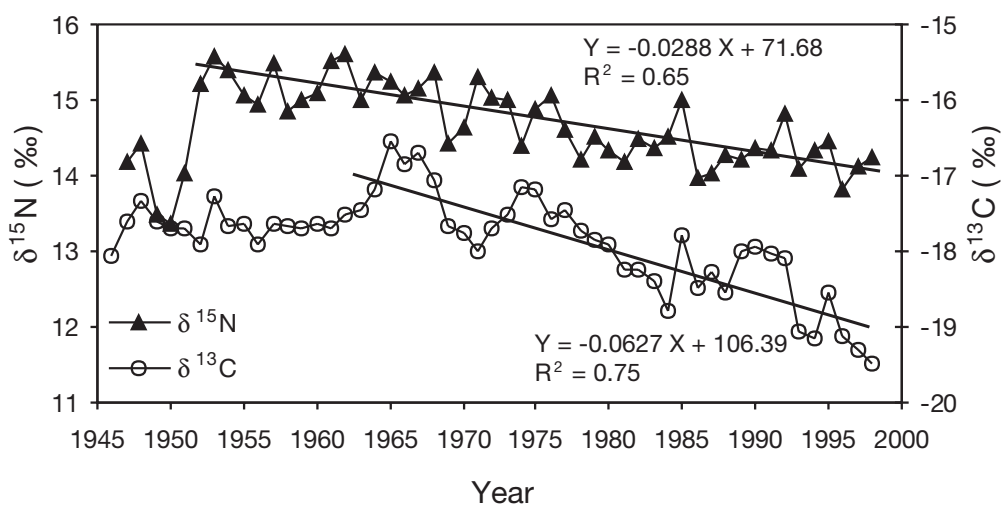

Fig. 3. Balaena mysticetus. Average carbon and nitrogen isotope ratios in the portions of 39 bowhead whale baleen plates laid down during feeding in the Bering and Chukchi seas each year over the past 5 decades. Standard deviations around each point (not shown) are ca. $\pm 0.5 \%$ for carbon and $\pm 0.6 \%$ for nitrogen. Straight lines are least-squares linear fits from 1965 to 1998 for carbon and from 1952 to 1998 for nitrogen (from Schell 2000, 2001)

we assume that the difference between $R_{\mathrm{Kak}}$ and $R_{\text {Barrow }}$ would equal the difference between $R_{\mathrm{EBF}}$ and $R_{\mathrm{BER}}$ if whales fed in the eastern Beaufort Sea to such an extent that the carbon in muscle turned over each season. This method does not require estimation of or allowance for any metabolic fractionation of ${ }^{13} \mathrm{C}$ in muscle tissue of the whale, but does assume that the spring ratio is based on $100 \%$ Bering-Chukchi carbon. The springharvested whales have been in the ${ }^{13} \mathrm{C}$-enriched Bering-Chukchi environment for over $7 \mathrm{mo}$, are known to feed there at least during autumn (Moore et al., 1995), and the $\delta^{13} \mathrm{C}$ values of the muscle during spring closely match ratios expected from an entirely Bering-Chukchi diet.

$R_{\text {Kak }}-R_{\text {Barrow }}$ : Since $1965, \delta^{13} \mathrm{C}$ ratios in the Bering-Chukchi seas have been declining (Schell 2000). Because our muscle samples

To compensate for this long-term trend, an additional $0.7 \%$ was added to the average $\delta^{13} \mathrm{C}$ values representing feeding on Bering-Chukchi zooplankton during 1997 to 1999. This allows direct comparisons of data from feeding in the late 1990s vs. the 1980s, and comparisons with the regional zooplankton data from the 1980s (Table 3). In some analyses of muscle data, a more precise adjustment was applied based on the specific year of collection (see next subsection).

It was assumed that the carbon isotope ratios in zooplankton of the eastern Beaufort Sea did not change between 1983-1987 and 1994-1998 (Table 4). There was no statistically significant difference between those periods, and baleen laid down in summer did not provide a basis for analyzing the long-term trend in isotopic ratios in the prey.

Fraction of bowheads feeding in the eastern Beaufort Sea. The proportion of the total annual food that is consumed in the eastern Beaufort Sea was calculated as the difference in $\delta^{13} \mathrm{C}$ ratios in muscle samples collected at Kaktovik in fall vs. Barrow in spring, divided by the difference in $\delta^{13} \mathrm{C}$ ratios of dietary components between the eastern Beaufort and Bering-Chukchi Seas. In equation form, the proportion of food consumed in the eastern Beaufort Sea was calculated as

$$
f=\frac{R_{\mathrm{Kak}}-R_{\mathrm{Barrow}}}{R_{\mathrm{EBF}}-R_{\mathrm{BER}}}
$$

where $R_{\text {Kak }}$ and $R_{\text {Barrow }}$ were the average muscle $\delta^{13} \mathrm{C}$ ratios in whales taken at Kaktovik (fall) and Barrow (spring), and $R_{\mathrm{EBF}}$ and $R_{\mathrm{BER}}$ were the average $\delta^{13} \mathrm{C}$ ratios of zooplankton collected in the eastern Beaufort Sea and Bering Sea.

$f$ can be interpreted as the proportion of annual food consumption occurring in the eastern Beaufort Sea if were taken at various times between the mid-1980s and late-1990s, an adjustment was made for overall decline when estimating $R_{\text {Kak }}$ and $R_{\text {Barrow. All }} \delta^{13} \mathrm{C}$ ratios in $R_{\text {Kak }}$ and $R_{\text {Barrow were adjusted to } 1999 \text { values }}$ by (1) fitting a linear regression to the post-1965 values in Table 1 of Schell (2000) (see also present Fig. 3), and (2) subtracting an appropriate amount based on the slope of this regression and the difference in years between the sampling date and 1999. For example, given that Schell (2000) estimated a decline in $\delta^{13} \mathrm{C}$ ratios of $-0.063 \%$ o $\mathrm{yr}^{-1}$, a $\delta^{13} \mathrm{C}$ ratio measured in 1987 would be adjusted by $-0.063 \% \mathrm{yr}^{-1} \times 12 \mathrm{yr}$ (1999 to $1987)=-0.756 \%$. $\mathrm{A} \delta^{13} \mathrm{C}$ ratio measured in 1998 would be adjusted by $-0.063 \%$, and a $\delta^{13} \mathrm{C}$ ratio measured in 1999 would not be adjusted. The standard error of the decline was estimated by the standard error of the slope of the regression. The year to which the standardization is made (here 1999) has no influence on the final results concerning estimated proportion of food consumption occurring in the eastern Beaufort Sea.

After adjustment of individual $\delta^{13} \mathrm{C}$ ratios for the long-term decline, $R_{\text {Kak }}$ and $R_{\text {Barrow }}$ were calculated as simple arithmetic averages. This method removed the long-term trend.

$R_{\mathrm{EBF}}$ and $R_{\mathrm{BER}}$ : Average $\delta^{13} \mathrm{C}$ in bowhead whale diets (i.e. $R_{\mathrm{EBF}}$ and $R_{\mathrm{BER}}$ ) were derived from values in Table 3 , and diet composition values in Table 2, considering only the 2 dominant taxa, copepods and euphausiids, as described in earlier subsection'Use of $\delta^{13} \mathrm{C}$ to assess feeding'.

Uncertainty in bowhead feeding fraction. To determine the uncertainty in the estimated proportion of bowhead feeding occurring in the eastern and central Beaufort Sea, we estimated the uncertainty in each parameter used to calculate $f$, and then derived the 
overall estimate. Uncertainty in $R_{\text {Kak }}$ and $R_{\text {Barrow }}$ was estimated by calculating yearly variances in individual $\delta^{13} \mathrm{C}$ ratios (see Table 6), and then a weighted average of these yearly variances. The weights were yearly sample sizes.

To estimate uncertainty in $R_{\mathrm{EBF}}$ and $R_{\mathrm{BER}}$, we first obtained standard errors (SE) for $\delta^{13} \mathrm{C}$ ratios in copepods and euphausiids in the Bering and eastern Beaufort Seas based on data in Table 1 of Schell et al. (1998) and the procedure of McDonald (2002). The SE of $R_{\mathrm{EBF}}$ and $R_{\mathrm{BER}}$ were each computed as $\mathrm{SE}(R)=\left[w_{1}{ }^{2} \operatorname{var}\left(r_{1}\right)+{w_{2}}^{2} \operatorname{var}\left(r_{2}\right)\right]^{0.5} /\left(w_{1}+w_{2}\right)$, where $W_{1}$ and $w_{2}$ were percent composition of copepods and euphausiids in the appropriate area, and $r_{1}$ and $r_{2}$ were corresponding $\delta^{13} \mathrm{C}$ values. For example, for the Bering Sea, the SE of $\delta^{13} \mathrm{C}$ in copepods was 0.16 and that in euphausiids was 0.21 (Schell et al. 1998, their Table 1). The SE of $R_{\mathrm{BER}}$ was $\left[(28 \%)^{2}(0.16)^{2}+(61 \%)^{2}(0.21)^{2}\right]^{0.5} /(89 \%)=$ 0.152 .

To calculate a $95 \%$ confidence interval for $f$, a Monte Carlo simulation was implemented, whereby random deviates from a normal distribution with mean 0 and appropriate standard deviation were repeatedly generated and added to the data comprising each component of $f$ (details in McDonald 2002). After Monte Carlo generation of $R_{\text {Kak }}, R_{\text {Barrow }}, R_{\mathrm{EBF}}$, and $R_{\mathrm{BER}}, f$ was recalculated. This process was repeated 1000 times, yielding 1000 random values of $R_{\text {Kak }}, R_{\text {Barrow, }}$ and $f$. From these values, SE of $R_{\mathrm{Kak}}$ and $R_{\text {Barrow }}$ and the $95 \%$ confidence interval for $f$ were derived.

Estimation of $f$ was performed for adult and subadult whales separately (distinguished by lengths of $\geq 13.5$ vs. <13.5 m). No samples were available from adults taken in spring at Barrow. Instead, $\delta^{13} \mathrm{C}$ values from 2 adults taken at Wainwright, Alaska (spring 1986), and 1 value taken at Gambell, Alaska (spring 1988), were used to calculate $R_{\text {Barrow }}$ for the adult analysis. $f$ was also estimated for adults and sub-adults combined, excluding the Wainwright and Gambell whales.

\section{RESULTS}

\section{Zooplankton isotope ratios in eastern Beaufort Sea}

The carbon and nitrogen isotope ratios found for the major taxonomic groups of zooplankton during 1998 and 1999 were very similar to those reported by Schell et al. (1998) for 1985 to 1995. Table 4 lists the carbon and nitrogen isotope ratios for copepods, euphausiids and chaetognaths in the present study and those from Schell et al. (1998). The 1998 and 1999 data are based on a limited number of stations in the eastern Alaskan
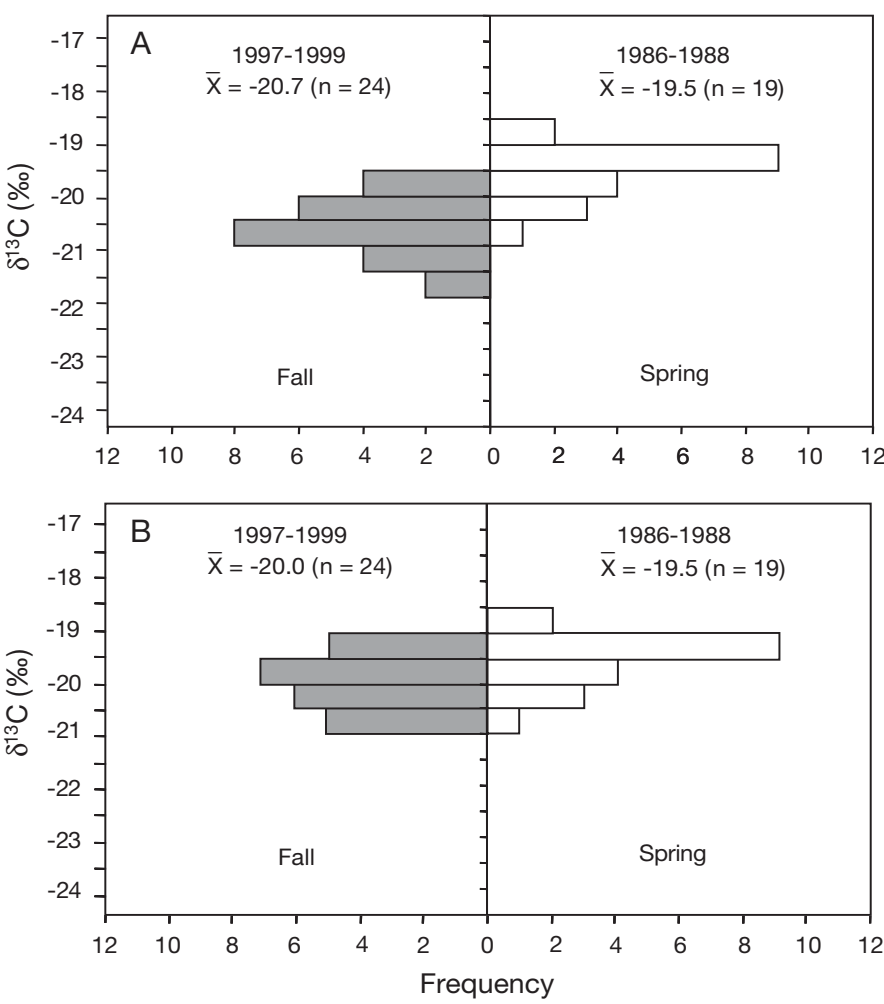

Fig. 4. Balaena mysticetus. $\delta^{13} \mathrm{C}$ values in bowhead whale muscle tissue taken in fall 1997 to 1999 as compared to values for spring 1986 to 1988. (A) Values as measured, not adjusted for decadal trend; (B) fall data adjusted for decadal change $(0.7 \%)$. Frequency: number of whale muscle samples

Beaufort Sea; the earlier data include samples from the Canadian as well as eastern Alaskan Beaufort Sea, in both coastal and offshore waters, for $7 \mathrm{yr}$. Based on the new eastern Alaskan data, we assumed when calculating food sources that the carbon isotope ratios in the zooplankton of the Beaufort Sea during the 1990s were similar to those reported in Schell et al. (1998).

\section{Seasonal isotope ratios in muscle}

Muscle tissues of 24 whales harvested in autumn 1997 to 1999 were analyzed. The isotope ratio data are listed in Table 5, along with results reported by Schell (1992) for 19 whales harvested in spring (and 6 in autumn) of 1986 to 1988. No muscle samples were obtained by us in spring during 1997 to 1999. Thus, we were constrained to using spring whale muscle data from Schell (1992) for comparison of fall vs. spring.

$\boldsymbol{\delta}^{\mathbf{1 3}} \mathbf{C}$ in bowhead muscle. Fall muscle for 1997 to 1999 exhibited a unimodal distribution of $\delta^{13} \mathrm{C}$ with a range from -22.0 to $-19.5 \%$, centered about a mode of -20.5 to $-21.0 \%$. By comparison, the spring muscle for 1986 to 1988 fell between -21.0 and $-18.5 \%$, with a 
mode at -19.0 to $-19.5 \%$ o (Fig. $4 \mathrm{~A})$. The average $( \pm \mathrm{SD})$ $\delta^{13} \mathrm{C}$ values differed by $1.2 \%$ : $-20.7 \pm 0.56 \%$ o $(\mathrm{n}=24)$ for fall 1997 to 1999 , and $-19.5 \pm 0.47 \%$ o $(\mathrm{n}=19)$ for spring 1986 to 1988 (Student's $t$-test $=7.11$, df $=41, \mathrm{p}<$ 0.001).

There are 2 possible reasons for lower $\delta^{13} \mathrm{C}$ values in whales killed in fall 1997 to 1999 than in spring 1986 to 1988 . This difference might mean the whales feed to a significant extent during summer in the eastern Beaufort Sea. Alternatively, if most feeding is in Bering-Chukchi water, a difference of about $0.7 \%$ would be expected based on the year-to-year decrease in average $\delta^{13} \mathrm{C}$ values in Bering-Chukchi biota noted above (third subsection of 'Materials and methods') (Fig. 3). The latter explanation is believed to be the major factor. After the $0.7 \%$ adjustment for the observed long-term decline in Bering-Chukchi isotopic averages over $10 \mathrm{yr}$, the average $\delta^{13} \mathrm{C}$ values in

Table 5. Balaena mysticetus. $\delta^{13} \mathrm{C}$ and $\delta^{15} \mathrm{~N}$ values for bowhead muscle tissues from 1997 to 1999 whales (this study) and 1986 to 1988 whales (Schell 1992). All 1997 to 1999 muscle tissue was collected from fall-killed whales; muscle samples for 1986 to 1988 were from spring-killed whales, except for 6 fall-killed whales indicated by asterisks. Muscle samples were not collected from Whales 97B8, 97B11 and 97B12. Data not corrected for decreasing decadal trends in $\delta^{13} \mathrm{C}$ and $\delta^{15} \mathrm{~N}$ in Bering-Chukchi Seas (Schell 2000, 2001). Mean and SD for 1986 to 1988 were calculated by excluding 6 fall-killed whales. NA: not applicable

\begin{tabular}{|c|c|c|c|c|c|c|c|}
\hline Whale & $\begin{array}{l}\text { Whale } \\
\text { length }(\mathrm{m})\end{array}$ & $\begin{array}{l}\delta^{13} \mathrm{C} \\
(\%)\end{array}$ & $\begin{array}{l}\delta^{15} \mathrm{~N} \\
(\%)\end{array}$ & Whale & $\begin{array}{l}\text { Whale } \\
\text { length }(\mathrm{m})\end{array}$ & $\begin{array}{l}\delta^{13} \mathrm{C} \\
(\%)\end{array}$ & $\begin{array}{l}\delta^{15} \mathrm{~N} \\
(\% \circ)\end{array}$ \\
\hline 97B8 & 13.6 & NA & NA & 86B1 & 8.2 & -19.43 & 15.24 \\
\hline 97B11 & 13.6 & NA & NA & 86B2 & 8.7 & -20.10 & 14.63 \\
\hline 97B12 & 15.3 & NA & NA & 86B3 & 8.9 & -20.56 & 12.64 \\
\hline 97B14 & 8.6 & -19.87 & 13.65 & 86B4 & 8.9 & -19.55 & 15.56 \\
\hline 97B16 & 8.3 & -20.80 & 14.91 & 86B5 & 8.1 & -19.10 & 14.42 \\
\hline 97B18 & 10.8 & -20.83 & 12.85 & 86B6 & 12.3 & -19.73 & 13.30 \\
\hline 97B20 & 8.6 & -20.62 & 13.00 & 86B7 & 10.7 & -20.11 & 15.56 \\
\hline 97B21 & 9.2 & -20.98 & 12.31 & ${ }^{*} 86 \mathrm{KK} 1$ & 7.6 & -21.45 & 13.91 \\
\hline 97B22 & 9.4 & -21.38 & 12.68 & *86KK2 & 17.1 & -19.12 & 13.86 \\
\hline 97B23 & 10.3 & -20.46 & 12.58 & ${ }^{*} 86 \mathrm{KK} 3$ & 10.4 & -21.38 & 14.97 \\
\hline 97B24 & 8.6 & -20.70 & 12.91 & 86WW1 & 15.9 & -18.84 & 14.38 \\
\hline 97B25 & 11.7 & -21.37 & 12.97 & 86WW2 & 17.7 & -19.35 & 13.62 \\
\hline 97B26 & 13.5 & -21.41 & 12.80 & 87B5 & 15.7 & -18.94 & 14.23 \\
\hline $97 \mathrm{~B} 27$ & 9.5 & -21.53 & 12.64 & *87B6 & 15.7 & -19.20 & 13.27 \\
\hline $97 \mathrm{~B} 28$ & 8.4 & -19.99 & 13.78 & *87B7 & 8.5 & -20.83 & 13.85 \\
\hline 97B29 & 8.5 & -20.00 & 13.46 & *87N1 & 16.8 & -20.85 & 12.89 \\
\hline $97 \mathrm{~B} 30$ & 8.0 & -21.78 & 14.45 & 88B1 & 8.9 & -20.16 & 14.55 \\
\hline 97KK1 & 8.7 & -20.79 & 12.85 & 88B2 & 8.8 & -19.43 & 14.80 \\
\hline 97KK2 & 13.2 & -20.42 & 12.94 & 88B3 & 7.8 & -19.24 & \\
\hline 97KK3 & 8.3 & -20.44 & 14.67 & 88B4 & 9.0 & -19.28 & 14.54 \\
\hline 97KK4 & 14.6 & -20.01 & 13.62 & $88 B 5$ & 8.9 & -19.43 & 13.80 \\
\hline 98KK1 & 10.4 & -20.47 & 12.40 & $88 B 6$ & 8.3 & -19.94 & 14.30 \\
\hline 98KK2 & 8.9 & -19.80 & 12.84 & $88 \mathrm{~B} 7$ & 8.2 & -20.30 & 14.43 \\
\hline 98KK3 & 9.2 & -21.30 & 12.54 & 88B8 & 7.5 & -19.52 & 13.97 \\
\hline 99KK1 & 7.7 & -20.91 & 13.72 & $88 \mathrm{G} 2$ & 15.3 & -19.06 & 13.90 \\
\hline 99KK2 & 12.9 & -20.49 & 12.60 & & & & \\
\hline 99KK3 & 8.3 & -20.87 & 12.66 & & & & \\
\hline Mean & & -20.72 & 13.16 & Mean & & -19.54 & 14.32 \\
\hline $\mathrm{SD}$ & & 0.56 & 0.72 & $\mathrm{SD}$ & & 0.47 & 0.76 \\
\hline
\end{tabular}

spring and fall muscle samples differed by only $0.5 \%$. The average $( \pm \mathrm{SD})$ muscle $\delta^{13} \mathrm{C}$ in fall, $-20.0 \pm 0.71 \%$ o ( $\mathrm{n}=30)$, was not significantly different ( $t$-test, 2 -tailed, $\mathrm{p}=0.33)$ from the spring average of $-19.5 \pm 0.47 \%$ o $(\mathrm{n}=$ 19; see also Fig. 4B). The fall sample $(\mathrm{n}=30)$ includes unadjusted data for six 1986 to 1987 whales (mean $-20.5 \pm 1.05 \%$ ) as well as adjusted data for 24 whales killed in 1997 to 1999 . The $\mathrm{p}=0.33$ value reported for the difference between the fall and spring values is understated because additional variation in the fall sample attributable to uncertainty in the $0.7 \%$ adjustment was not accounted for in the $t$-test. Thus, after justment for the long-term trend in $\delta^{13} \mathrm{C}$ values, the spring and fall.

$\boldsymbol{\delta}^{\mathbf{1 5}} \mathbf{N}$ in bowhead muscle. Whales taken in fall 1997 to 1999 had muscle samples with a mean $( \pm \mathrm{SD}) \delta^{15} \mathrm{~N}$ value of $13.2 \pm 0.72 \%$ o (Fig. 5), whereas spring muscle samples for 1986 to 1988 had an average $\delta^{15} \mathrm{~N}$ of $14.3 \pm 0.76 \%$, an enrichment of $1.2 \%$. The average $\delta^{15} \mathrm{~N}$ value for the 6 autumn-killed whales from the 1986 to 1987 samples (13.8 \pm $0.71 \%$ ) was intermediate between spring whales in the 1980s and fall whales in the 1990s. The $\delta^{15} \mathrm{~N}$ values in fall muscle (including 6 fall-killed 1986 to 1988 whales) were significantly different from those in the spring muscle ( $t$-test, 2 tailed, p < $0.001)$, although the $\delta^{15} \mathrm{~N}$ values of the main prey groups did not differ significantly between summer and winter feeding grounds. $\delta^{15} \mathrm{~N}$ as well as $\delta^{13} \mathrm{C}$ values in muscle have decreased in the past decade, apparently in response (at least in part) to long-term decreases in isotope values in the Bering-Chukchi environment (Fig. 3). This may account for the difference in $\delta^{15} \mathrm{~N}$ of muscle in Fig. 5, although the $\delta^{15} \mathrm{~N}$ values in baleen deposited in 1986 to 1988 and in 1997 to 1999 did not show a significant change (Fig. 3).

\section{Bowhead feeding fraction, $f$}

In 1986 to 1988 , a total of 16 muscle-tissue samples were obtained from whales taken in the spring at Barrow ( 7 in 1986, 1 in 1987, 8 in 1988). In 1986 and 1997 to 1999, 13 muscle tissue samples were obtained from whales taken in the fall at 


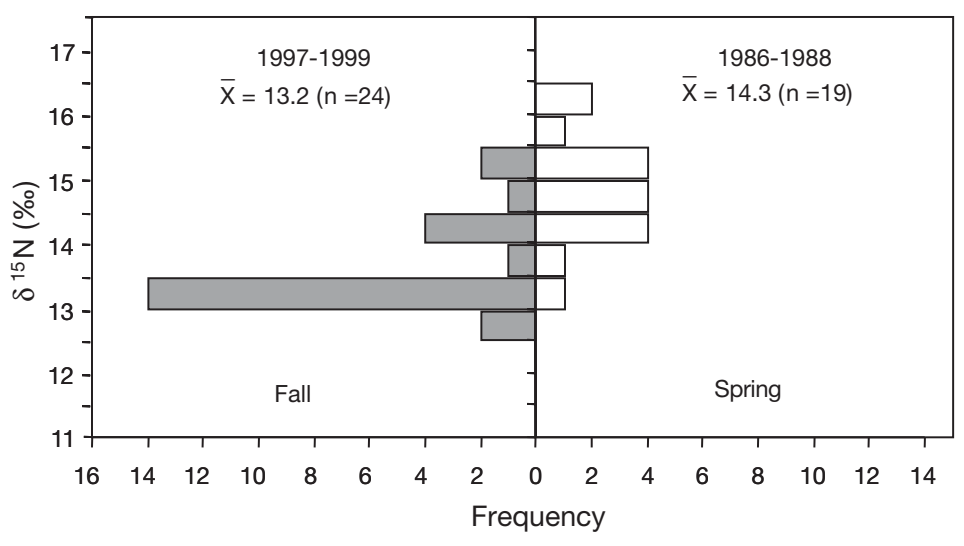

Fig. 5. Balaena mysticetus. $\delta^{15} \mathrm{~N}$ values in bowhead whale muscle tissue taken in fall 1997 to 1999 compared to values for spring 1986 to 1988. Values as measured, not adjusted for decadal trend. Frequency: number of whale muscle samples

Kaktovik (3 in 1986, 4 in 1997, 3 in 1998, 3 in 1999). All 16 whales sampled at Barrow were sub-adults. Of 13 whales taken at Kaktovik, 2 were adults and 11 were sub-adults.

Estimates and standard errors of $R_{\mathrm{EBF}}, R_{\mathrm{BER},}, R_{\mathrm{Kak}}$ $R_{\text {Barrow, }}$ and of the long-term trend in $\delta^{13} \mathrm{C}$ ratios are given in Table 6, derived as explained in 'Materials and methods'. Assuming that each component of $f$ followed a normal distribution with mean and standard deviation as listed in Table 6, the proportion of diet consumed in the eastern Beaufort Sea by subadult bowhead whales was $13.7 \%$, with a $95 \%$ confidence interval of 4.3 to $23.3 \%$. The estimated proportion of diet consumed in the eastern Beaufort Sea by

Table 6. Balaena mysticetus. Estimates and standard errors of $\delta^{13} \mathrm{C}$ ratios used in calculation of $f$. Mean $\delta^{13} \mathrm{C}$ values in subadult and adult whale tissue adjusted to 1999 values based on long-term trend. Standard errors of mean estimates exceed standard deviation divided by $\sqrt{ } \mathrm{n}$ because values were adjusted to 1999 levels and there is inherent uncertainty in the adjustment. SDs established by Monte Carlo simulation

\begin{tabular}{|lllllc|}
\hline Age & Statistic & Estimate & SE & SD & $\mathrm{n}$ \\
\hline Subadult & $R_{\text {Kak }}$ & -20.96 & 0.130 & 0.425 & 11 \\
& $R_{\text {Barrow }}$ & -20.43 & 0.138 & 0.437 & 16 \\
Adult & $R_{\text {Kak }}$ & -20.03 & 0.457 & 0.629 & 2 \\
& $R_{\text {Barrow }}$ & -19.85 & 0.180 & 0.294 & $3^{\mathrm{a}}$ \\
All & $R_{\text {Kak }}$ & -20.81 & 0.211 & 0.761 & 13 \\
& $R_{\text {Barrow }}$ & -20.43 & 0.138 & 0.437 & 16 \\
& $R_{\text {EBF }}$ & -25.10 & 0.151 & - & - \\
& $R_{\text {BER }}$ & -21.24 & 0.152 & - & - \\
a Comprises 2 whales taken at Wainwright and 1 taken at \\
Gambell; these 3 whales were not included in the 'all \\
whale' analysis & Trend & -0.0629 & 0.00648 & - & \\
\hline
\end{tabular}

adults was $4.6 \%$, with a $95 \%$ CI of 0 to $30.0 \%$. Combining age classes, the estimated proportion of diet consumed in the eastern Beaufort Sea was 10.0\%, with a $95 \%$ CI of 0 to $22.6 \%$.

\section{Isotope ratio patterns of subadult versus adult whales}

Muscle. To assess the extent to which subadults and adults feed differently, all muscle data for $\delta^{13} \mathrm{C}$ and $\delta^{15} \mathrm{~N}$ are plotted against whale length in Figs. $6 \& 7$. Subadults were separated by body length $(<13.5 \mathrm{~m})$ from adults $(\geq 13.5 \mathrm{~m})$. The $13.5 \mathrm{~m}$ cutpoint is appropriate for bowhead whales that have been stretched when towed out of the water. No significant differences were noted in $\delta^{13} \mathrm{C}$ or $\delta^{15} \mathrm{~N}$ in subadult vs. adult whale muscle.

Baleen. Fig. 8 shows $\delta^{13} \mathrm{C}$ and $\delta^{15} \mathrm{~N}$ values for each sampling point within parts of the baleen formed during the most recent 2 or $3 \mathrm{yr}$, distinguishing adults $(\mathrm{n}=9+4)$ and subadults $(\mathrm{n}=9+8)$. Results for 1997 to 1999 and for 1986 to 1988 are plotted separately. The range in $\delta^{13} \mathrm{C}$ values was greater in subadults than in adults for both time periods (Fig. 8). The range of $\delta^{13} \mathrm{C}$ for adults was -20.0 to $-17.0 \%$ for 1986 to 1988 and -21.0 to $-17.5 \%$ o for 1997. In comparison, $\delta^{13} \mathrm{C}$ values of subadults ranged from -23.0 to $-17.5 \%$ o both for 1986 to 1988 and for 1997 to 1999 . $\delta^{15} \mathrm{~N}$ values in recently grown baleen also spanned a slightly wider range for subadults than for adults (Fig. 8). The range of $\delta^{15} \mathrm{~N}$ in adults was from 12.5 to $16.0 \%$ for both periods, whereas the range in subadults was 12.5 to $17.0 \%$ for 1986 to 1988 and 11.0 to $16.0 \%$ for 1997 to 1999 .

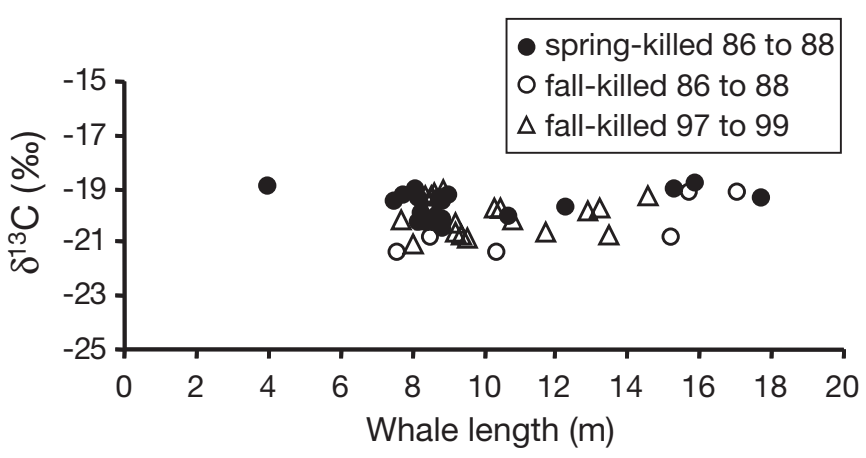

Fig. 6. Balaena mysticetus. Carbon isotope ratios in whale muscle versus whale length. Whales $>13.5 \mathrm{~m}$ in body length were assumed to be adults (sexually mature). Data from 1997 to 1999 adjusted upward to allow for decadal decline in average carbon isotope ratios $(0.7 \%)$ 


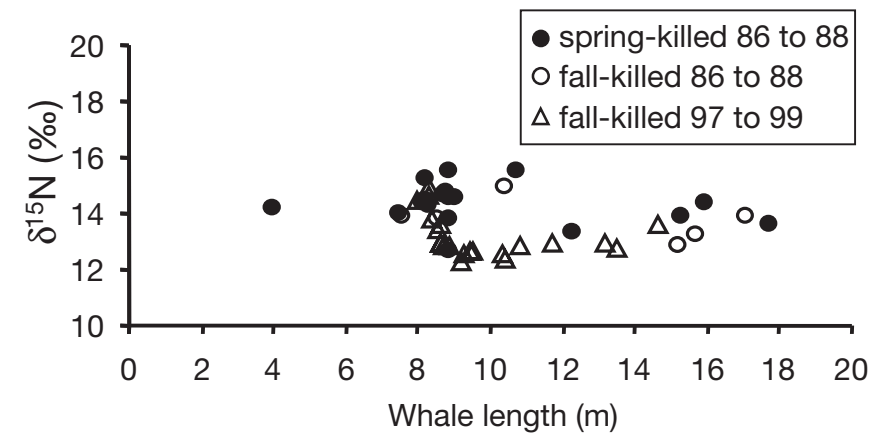

Fig. 7. Balaena mysticetus. Nitrogen isotope ratios in whale muscle versus whale length. Whales $>13.5 \mathrm{~m}$ in body length were assumed to be adults (sexually mature). Values not adjusted for any decadal trend

\section{DISCUSSION}

\section{Bowhead feeding activity based on stable isotope analysis}

Muscle tissue $\delta^{13} \mathrm{C}$ values provide a good overall indication of the bulk food sources that whales have consumed over their seasonal feeding cycle. George et al. (1988) estimated that muscle tissue comprises $~ 19 \%$ of the total body mass, with blubber comprising the other large fraction. The estimated $\delta^{13} \mathrm{C}$ values for total
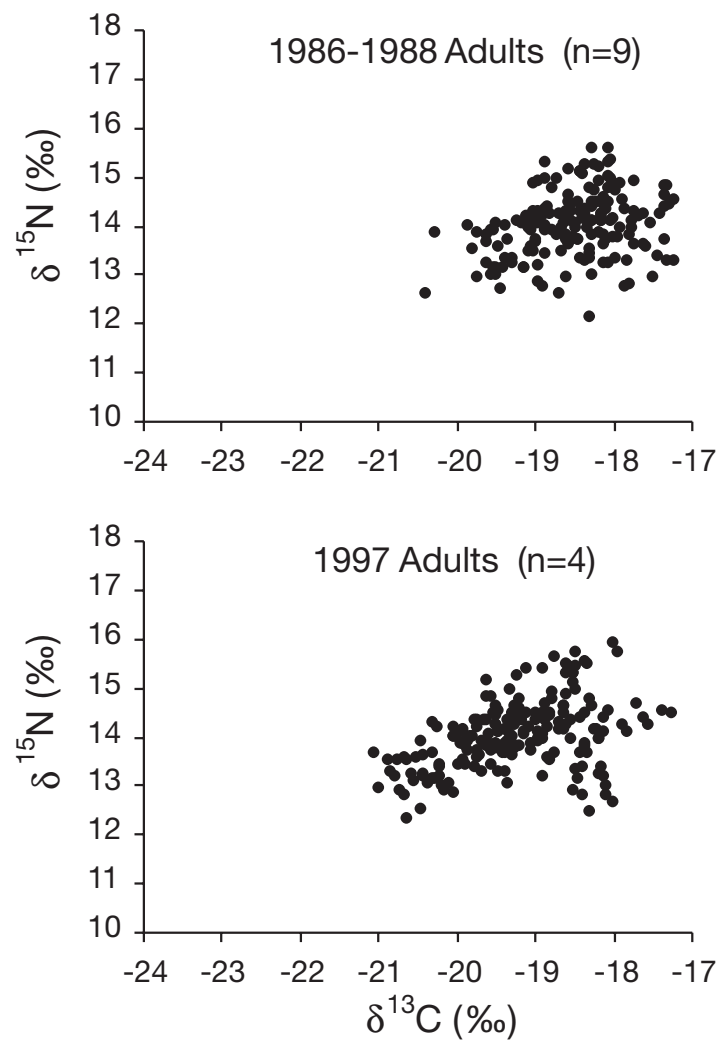

consumed prey are significantly different between the eastern Beaufort Sea and the Bering and Chukchi Seas (see 'Materials and methods'). Therefore, muscle tissue should change appreciably in $\delta^{13} \mathrm{C}$ between the spring-summer and the fall-winter seasons if (1) whales feed to a significant extent in each region, (2) regional diet composition (Table 2) is approximately representative, and (3) turnover is fast enough for muscle composition to change from season to season. However, the $\delta^{13} \mathrm{C}$ values in fall muscle, predominantly in the late-1990s, were not significantly different from those in the spring muscle from the 1980s after adjustment for the $0.7 \%$ ong-term decline observed in Bering-Chukchi isotopic averages over the intervening $\sim 11 \mathrm{yr}$. Also, $\delta^{13} \mathrm{C}$ values in both spring and fall muscle were similar to those in zooplankton from the Bering-Chukchi system, indicating that most food for the whales came from Bering-Chukchi waters.

We calculated the estimated turnover in muscle carbon attributable to feeding in the eastern Beaufort Sea, based on the data from whales harvested at Barrow in spring of 1986 to 1988 ( $\mathrm{n}=16$ ) and at Kaktovik in autumn of 1986 and 1997 to 1999 ( $n=13)$. This calculation included an adjustment for the long-term trend in Bering-Chukchi isotopic averages, and included derivation of confidence limits. We assumed a dietary
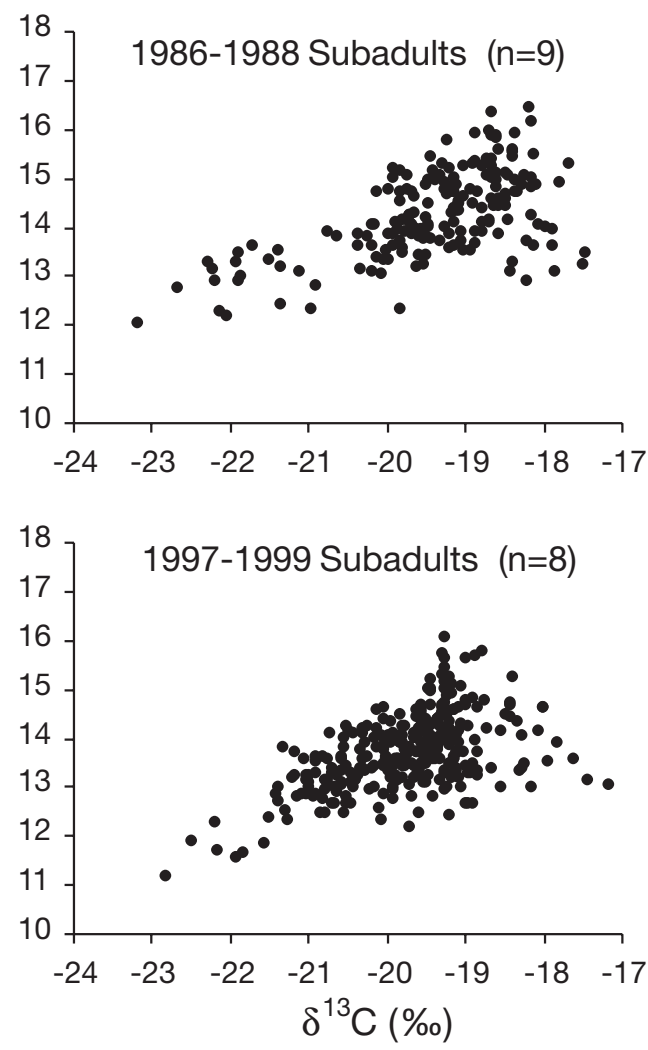

Fig. 8. Balaena mysticetus. $\delta^{13} \mathrm{C}$ and $\delta^{15} \mathrm{~N}$ values from recently deposited baleen of adult and subadult bowhead whales. Each data point represents a sample taken 0 to $50 \mathrm{~cm}$ from base of a baleen plate from an adult whale harvested in 1986 to 1988 or 1997 to 1999. Values not adjusted for any decadal trend 
composition of $61 \%$ copepods and $22 \%$ euphausiids in the eastern Beaufort Sea, vs. $28 \%$ copepods and $61 \%$ euphausiids in Bering-Chukchi waters (from Lowry et al. in press). As noted earlier, there are questions as to how representative these dietary data may be, especially for fall-feeding in the Bering-Chukchi system. However, the similarity in taxonomic composition of stomach contents and samples from net tows (Saupe et al. 1989, Schell et al. 1998) gives some indication that the approximations are reasonable.

The major assumption and weakness of the preceding analysis arises from the need to compare seasonal isotope ratios in whales harvested $\sim 10 \mathrm{yr}$ apart. The changing isotope ratios in zooplankton of the Bering and Chukchi Seas (and perhaps the Beaufort Sea) introduce an uncertainty into the feeding estimates that is difficult to quantify, notwithstanding the statistical procedures used (see 'Materials and methods').

\section{Estimation of feeding activity using same-year data}

A recent paper by Hoekstra et al. (2002) contrasts isotope ratios of bowhead whales taken within the same years in spring and fall. This should allow a more direct approach to estimation of feeding, as evidenced by the turnover of carbon in muscle tissue. Hoekstra et al. (2002) determined that the 10 whales taken in fall at Kaktovik during 1997 to 1999 (the years of our sampling) had an average muscle $\delta^{13} \mathrm{C}$ of $-21.6 \%$ and that 28 whales taken in spring at Barrow during 1998 to 2000 averaged $-19.9 \%$, i.e. a seasonal shift of $-1.7 \%$. Assuming $\delta^{13} \mathrm{C}$ values of $-20.9 \%$ for prey from Bering-Chukchi waters and $-25.5 \%$ for prey from the Beaufort Sea (Schell et al. 1998), this implies a muscle carbon turnover of $-1.7 \%$ o/ $-4.6 \%$ o (i.e. $-25.5 \%$ - $(-20.9 \%$ o) $)$ or $37 \%$. Alternatively, assuming a $3.9 \%$ difference in the isotopic composition of the prey in the 2 regions (see preceding subsection), and the $1.7 \%$ seasonal difference in the muscle as observed by Hoekstra et al. (2002), 45\% of the muscle carbon will have turned over during the course of summer feeding.

The above estimates of summer-feeding, based on the data of Hoekstra et al. (2002), are much higher than those determined by us based on either the analysis with allowance for long-term trends (see preceding subsection) or additional analyses of same-year data, described below.

We found an average muscle $\delta^{13} \mathrm{C}$ of $-20.7 \%$ in Kaktovik whales during the autumns of 1997 to 1999, i.e. $-0.8 \%$ compared with the spring values from Barrow during the same years obtained by Hoekstra et al. (2002). This translates into $17.4 \%$ turnover of muscle carbon during summer feeding based on the assumed $4.6 \%$ difference in the isotopic composition of zoo- plankton in the 2 regions, or $20.8 \%$ if the weighted value $(3.9 \%$ ) based on stomach contents is used. Comparing our average muscle values for Kaktovik in autumn $(-20.7 \%$ o) with theirs for Barrow in autumn $(-20.9 \%)$, we find a small and non-significant depletion in the muscle $\delta^{13} \mathrm{C}$ of the whales while traveling westward, in contrast to Hoekstra et al. (2002), who found an average increase in autumn $\delta^{13} \mathrm{C}$ values of $0.7 \%$ o between Kaktovik and Barrow, equivalent to a muscle turnover of 15 to $18 \%$.

These differences are critical in assessing the importance of feeding in the eastern Beaufort Sea. This apparent discrepancy between the 2 studies arises from differences in the results for the muscle samples from whales harvested at Kaktovik in autumn. Hoekstra et al. (2002) found an average muscle value of $-21.6 \%$ in 1997 to 1999 , whereas we obtained an average value of $-20.7 \%$ from the same whales. We have repeated our isotopic analyses on additional subsamples from the same Kaktovik whales, with the same results. The reason for the discrepancy between our data from Kaktovik and those of Hoekstra et al. (2002) is still uncertain. We have analyzed the isotope ratios for muscle from 14 fall Barrow whales taken in 1997 and obtained an average $( \pm \mathrm{SD})$ of $-20.8 \pm 0.6 \%$. This closely matches the average value of $-21.1 \pm 95 \%$ (CI $0.2 \%$ ) obtained by Hoekstra et al. (2002) for 21 whales harvested at Barrow in fall 1997. We also analyzed 3 types of muscle from one 1997 Kaktovik whale, including lumbar muscle, and found no significant difference among muscle tissues. This suggests that differences in the types of muscle samples analyzed were probably not important.

In view of the above, we applied this approach to small samples of same-year data collected in 1986 to 1987 by Schell (1992): 7 whales taken in spring at Barrow had average $\delta^{13} \mathrm{C}$ values of $-19.6 \%$ for muscle and $-24.9 \%$ for visceral fat; 3 whales taken at Kaktovik in fall 1986 had average $\delta^{13} \mathrm{C}$ values of $-20.6 \%$ for muscle and $-26.3 \%$ for visceral fat. Thus, the seasonal change was $1.0 \%$ in muscle and $1.3 \%$ in visceral fat. Again, assuming an end-member difference of $4.6 \%$, this implies a replacement of about $22 \%$ of muscle carbon and $28 \%$ of visceral fat. If the stomach content data of Lowry et al. (in press) are used to indicate seasonal diet composition, the end-member difference is $3.9 \%$ and the carbon replaced is $26 \%$ based on muscle data and $34 \%$ based on visceral fat. These same-year estimates of turnover are higher than those we derived (see 3rd subsection of 'Results') based on larger samples of multiyear data, but lower than the 37 to $45 \%$ values based on the data of Hoekstra et al. (2002).

In contrast to the relatively rapid turnover rates of visceral fat and muscle, the blubber lipids showed very little change: 2 whales taken at Barrow in 1986 each 
had blubber $\delta^{13} \mathrm{C}$ values of $-25.8 \%$; the 3 whales from Kaktovik averaged $-26.0 \%$, i.e. a change of only $0.2 \%$ over the summer. This implies a turnover of only about 4 to $5 \%$, depending upon the choice of end-member differences. The carbon isotope ratio in lipids is typically depleted by 5 to $6 \%$ from that in the diet (Schell et al. 1989), so the measured values in blubber closely match values that would be expected for whales feeding on Bering-Chukchi zooplankton.

Our same-year estimates of changes of 17 to $26 \%$ for muscle tissue and 28 to $34 \%$ for visceral fat are low considering that the whales had been in the ${ }^{13} \mathrm{C}$ depleted regime of the eastern Beaufort Sea for $\sim 4$ mo. Muscle amino-acid turnover in terrestrial mammals, as measured using stable and radio-isotope measurements, ranges from 1.2 to $3 \% \mathrm{~d}^{-1}$ for healthy adult humans and dogs, leading to an expected complete replacement time of 33 to $80 \mathrm{~d}$ (Fischman et al. 1998). The turnover rates we calculated are based upon the changing isotope ratios and depend upon the assumptions that (1) the turnover rate in isotopic composition is essentially uniform throughout the whale, with only small variations between same types of tissue, and (2) the whale does not perform significant isotope discrimination in respiration or metabolism of its food. This latter assumption has been documented for many heterotrophs. If the lower mass-specific metabolic rate of the whale reduces the specific rate of amino-acid turnover, the complete replacement time for body protein would be longer than 33 to $80 \mathrm{~d}$. The low isotopic replacements observed in this study indicate either that the metabolic rates of the bowhead whale are slow or that very little food is acquired from the Beaufort Sea, or both. The latter scenario is supported by the very small seasonal isotopic changes observed in blubber tissue in the 1980s.

Isotope ratios in the blubber of bowhead whales landed at Barrow and Kaktovik during the 1990s were not determined during either the present study or that of Hoekstra et al. (2002) (Paul Hoekstra pers. comm.). This information would be valuable in estimating the percent of total annual carbon intake derived from the winter versus summer habitats. Blubber comprises $\sim 40 \%$ of bowhead body mass and is the major energy store for the whales (George et al. 1988).

\section{Postulated bowhead-whale feeding scenario}

To assess the contribution of food from Beaufort Sea habitats in meeting the annual energy requirements of the Bering-Chukchi-Beaufort stock of bowheads, it is important to take into account time and resource availability as well as direct evidence of feeding, such as stomach contents and observed feeding behavior. The following feeding scenario is based upon several realistic assumptions concerning food availability and mammalian metabolism:

- Bowhead whales feed seasonally in response to food abundance. In spring, feeding is minimal during the northeastward transit through the Arctic Ocean to summer grounds.

- Zooplankton abundance is proportional to ecosystem primary productivity.

- Zooplankton abundance peaks in the late summer/ fall season.

- Zooplankton composition is weighted to euphausiids in the Bering-Chukchi region and to copepods in the eastern Beaufort Sea.

- Isotope ratios in the whales respond to feeding in the different regimes only if sufficient food is acquired to replace body carbon. Otherwise the whale relies on internal stores and the isotope ratios of the muscle do not change.

This scenario assumes that the whales begin their northward migration in early spring, when zooplankton stocks are at an annual minimum, and that this condition persists during most of their passage through the Chukchi Sea and into the Arctic Ocean. Feeding behavior is occasionally observed near Barrow in spring (Carroll et al. 1987), and $33 \%$ of the bowheads harvested at Barrow in spring contain some prey, but on average their stomachs contain considerably less food than those harvested at Kaktovik and Barrow in autumn (Lowry et al. in press). Also, feeding is much less commonly seen during spring migration than during summer and autumn (Würsig et al. 2002). The whales arrive in the eastern Beaufort Sea after 2 to 3 mo travel, probably with minimal feeding having occurred along the migration route. More intensive feeding occurs on the summering grounds (Würsig et al. 1985, 1989), with the appearance of growing populations of large copepods and amphipods (Bradstreet et al. 1987). Nevertheless, zooplankton patch densities in the Beaufort Sea are constrained by the relatively low primary productivity of that area, typically 20 to $50 \mathrm{gC}$ $\mathrm{m}^{-2}$ in offshore regions. The higher values occur in zones of upwelling associated with offshore winds and open polynyas (Macdonald et al. 1987, 1998, Macdonald \& Carmack 1991). Zooplankton biomass and whale feeding would be anticipated to increase at the end of summer.

Most whales begin their fall migration out of the Beaufort Sea in September, feeding intermittently as they travel (Würsig et al. 2002). On average, they move into the areas where the zooplankton has higher isotope ratios (west of Harrison Bay, Longitude $\sim 152^{\circ} \mathrm{W}$ ) in late September and early October (see Moore \& Reeves 1993). Here they apparently feed, at least in part, on zooplankton advected from the Chukchi Sea 
associated with the Beaufort Sea undercurrent. As the fall progresses, the whales move into the Chukchi Sea, with many if not all crossing to the Chukotka Peninsula region of Russia (Fig. 1), in the highly productive waters of the Anadyr current. Primary productivity estimates for this region range from $150 \mathrm{gC} \mathrm{m}^{-2}$ in coastal waters to over $800 \mathrm{gC} \mathrm{m}^{-2}$ in the center of the Anadyr flow, i.e. $\sim 5$ to 10 times the estimates for the eastern Beaufort Sea (Springer et al. 1996). This flow carries immense quantities of euphausiids and large oceanic copepods. Thus, the whales enter the Chukchi Sea in the fall coincident with maximum annual food supply, and at least some bowheads feed upon these resources (Moore et al. 1995). Secondary production of zooplankton is proportional, but not linearly so, to primary productivity, with increasing trophic efficiency occurring with higher primary production. Thus, the feeding opportunities for the whales would be maximized in this region. Niebauer \& Schell (1993) quoted whaler observations describing the southern Chukchi Sea as the 'cow yard', where the very largest and most oil-rich bowheads were taken. Feeding in reasonably dense concentrations of zooplankton could continue in late autumn/early winter as the whales move southward into the NW Bering Sea.

Assuming that the high zooplankton densities persist at least into the early winter, the fall migration past Point Barrow would correspond to the onset of the optimum feeding period for the whales. Although energyrich zooplankton tend to descend to deep depths in autumn, the Chukchi Sea is generally shallow. This would prevent zooplankton from descending to depths below the diving range of bowheads. If feeding in the Bering-Chukchi system persists until late autumn or early winter, when growing ice cover forces the whales into the Bering Sea, their period of autumn/earlywinter residence in the Chukchi Sea, and perhaps the NW Bering Sea, may be the period of maximum energy acquisition and storage. The observation that the 5 blubber samples from whales taken in 1986 all had similar $\delta^{13} \mathrm{C}$ values near $-25.8 \%$ supports this conclusion. As noted in the preceding subsection, lipids are typically depleted by 5 to $6 \%$ relative to diet, and this $-25.8 \%$ value closely matches values expected from feeding on Bering-Chukchi zooplankton.

\section{Nitrogen isotope data}

We found that the $\delta^{15} \mathrm{~N}$ values in fall muscle are significantly different from those in the spring muscle, but Hoekstra et al. (2002) found no seasonal changes in $\delta^{15} \mathrm{~N}$ values of bowhead muscle. The nitrogen isotope ratio is often an indicator of nutritional status (e.g. Gannes et al. 1997), but the specific reason for the observed difference is uncertain. One possibility is that it results from the same decadal decline in environmental isotope ratios as noted for carbon. The spring whales were all taken in the 1980s, whereas the fall whales were mainly from the late 1990s. The long-term trend noted for both elemental isotope ratios (based on baleen deposited in the Bering-Chukchi region) is of the same magnitude as the difference between the spring muscle from the 1980 s vs. the fall muscle from the 1990s. However, the nitrogen isotope data evident in baleen laid down in the specific years of capture in the 1980s and 1990s for our sampled whales were similar (Fig. 3). This tends to discount the possibility that a decadal decline was the cause of the spring-fall difference in the muscle $\delta^{15} \mathrm{~N}$ values. A second possibility is that summer fasting (or more likely 'near-fasting') produced a shift toward higher $\delta^{15} \mathrm{~N}$ values (Hobson et al. 1993, 1996, Best \& Schell 1996). The seasonal change in $\delta^{15} \mathrm{~N}$ is unlikely to arise from summer feeding, as the carbon isotope ratios in muscle would be expected to show a larger eastern Beaufort signature if a significant amount of food were consumed in summer. Additionally, the $\delta^{15} \mathrm{~N}$ values in the assumed main prey taxa are not significantly different between summer and winter feeding grounds, so summer feeding alone would not affect $\delta^{15} \mathrm{~N}$ values.

\section{Feeding by subadult versus adult bowheads}

The carbon turnover calculations (see 3rd subsection of 'Results') suggest that subadult bowheads may obtain slightly more of their prey in the Beaufort Sea than do adults, but the best estimates for both groups are low, and there is wide overlap in the $95 \%$ confidence intervals.

Younger whales have often been observed feeding in nearshore waters of the eastern Beaufort Sea, whereas adults tend to occupy deeper waters when in this area (Würsig et al. 1989, Koski \& Miller 2002). For this or other reasons, it is possible that feeding patterns, as represented by isotope ratios, would be related to age. However, $\delta^{13} \mathrm{C}$ values in muscle are similar in adults and subadults, suggesting no major age-related shift in the relative importance of feeding in the eastern Beaufort Sea vs. elsewhere.

In contrast to the muscle data, $\delta^{13} \mathrm{C}$ values in the baleen plates do show considerable age-related differences, indicating some variation in feeding patterns between subadult and adult bowheads (Fig. 8). Each point along the plates records the isotopic values of the amino acid baleen precursors at the time of baleen formation, whereas muscle shows bulk isotopic composition of whales integrated over an extended (but uncer- 
tain) period. The small mass of baleen being formed at a given time relative to the much larger muscle mass would allow the baleen laid down at that time to respond quickly to changing isotope ratios in amino acids derived from digested food. The lack of low $\delta^{13} \mathrm{C}$ values in either baleen or muscle of adult bowheads suggests that they feed predominantly in the Bering and Chukchi Seas and that the observed feeding by adults in the eastern Beaufort Sea during summer and early fall must be incidental in amount. In contrast, the wider range in baleen isotope ratios in subadults suggests that they apparently feed continually while they are migrating across regions of different isotope ratios. However, the average muscle and baleen $\delta^{13} \mathrm{C}$ values in subadults as well as adults tend to match prey from Bering and Chukchi waters. This suggests that feeding is more successful there which may, in turn, reflect the higher primary and secondary productivity of the Bering-Chukchi region.

The consumption of different prey by adults versus subadults in summer might also account for the different isotopic compositions. However, no major differences between the diets of small and large whales were evident from stomach content samples collected at Kaktovik and Barrow over many years (Lowry et al. in press). Both adults and subadults probably feed on any species of zooplankton that is sufficiently concentrated to provide a reasonable energy source (Griffiths et al. 2002). However, differences in the locations and water depths where subadult and adult bowheads tend to concentrate (Koski \& Miller 2002) can be associated with differences in prey. Subadult bowheads commonly feed in nearshore waters along the Yukon and eastern Alaskan coast at locations and times when the small copepod Limnocalanus spp. is concentrated. Adult bowheads tend to be seen farther offshore, in areas without Limnocalanus spp. (Griffiths et al. 2002).

In summary, the utilization of feeding habitats appears to be more diverse for subadult than adult bowheads, as indicated by the larger range in isotope ratios in subadult baleen. In contrast to some other types of data, isotopic evidence indicates that the eastern Beaufort Sea is not an important feeding habitat for adult bowhead whales. It may be more important for subadults. However, isotopic values in both bulk body tissues and the baleen plates indicate that the Bering and Chukchi regions are the predominant feeding areas for both adults and subadults. The specific estimates of the percent of the feeding that occurs in the eastern Beaufort Sea are subject to a variety of assumptions and vary depending on the particular sample of data considered. However, the strong Bering-Chukchi isotopic signature in muscle and baleen, as compared with the much more limited east- ern Beaufort signature, indicates that only a fraction of feeding by either subadults or (especially) adults is on prey from the eastern Beaufort region.

\section{CONCLUSIONS AND PROSPECTS}

Our new stable isotope data continue to indicate that the Bering-Chukchi-Beaufort population of bowhead whales acquires the bulk of its annual food intake from the Bering-Chukchi system, where the whales spend much of the fall plus the winter and early spring. Our data indicate that they acquire only a minority of their annual diet from the eastern and central Beaufort Sea, where they spend the summer, although subadult bowheads apparently feed there somewhat more often than do adults. These results are surprising in consideration of (1) the fact that other species of baleen whales feed predominantly in summer, and (2) other evidence of feeding by bowheads in the eastern and central Beaufort Sea in summer and early autumn. The various types of data are perhaps partly reconcilable on the basis that prey biomass is lower in the Beaufort Sea than in the Bering-Chukchi system, and that the observed summer feeding in the Beaufort Sea may not be as efficient as autumn feeding in the more productive Bering-Chukchi waters.

While our isotope-based data seem to show that only a fraction of the annual feeding by bowheads occurs in the eastern and central Beaufort Sea, the specific estimates of the proportion of the annual diet acquired there are subject to many assumptions and uncertainties. The differences between our Kaktovik data and those of Hoekstra et al. (2002) raise further questions. Additional same-year spring and fall data on isotope ratios in muscle, visceral fat, and blubber would be valuable in refining the present estimates and the overall understanding of seasonal feeding by bowheads.

Although zooplankton prey samples have been collected from almost all of the known range of this population of bowhead whales, muscle samples have only been available and analyzed for selected locations and seasons. No muscle samples from whales harvested along the Chukotsk Peninsula (SW Chukchi Sea) or at St. Lawrence Island (Bering Sea) have been analyzed. Also, in the absence of regular bowhead harvests in the Canadian Beaufort Sea, muscle samples from that area have not been available for analysis.

The baleen, however, grows continuously and reflects the isotopic composition of the food recently consumed. Additional fine-scale analyses of the isotope composition of baleen could be useful in lieu of (or to supplement) analysis of tissue samples collected at other locations. For example, by analyzing the isotope 
ratios of individual amino acids in the baleen and comparing them with the same amino acids from prey, many of the uncertainties noted above probably could be better addressed. Future work on isotope ratios of individual essential amino acids from prey in different regions, and on the isotope ratios in specific fatty acids, might also provide more definitive insights into both habitat and prey quality. Similarly, the analysis of oxygen isotope ratios in baleen and prey should allow resolution of offshore versus inshore feeding in the eastern Beaufort Sea, where the influence of the Mackenzie River is pronounced. Isotopic signatures and compositional changes in fatty acids may also provide additional insight into feeding regimes.

Acknowledgements. We thank the whaling captains of Barrow and Kaktovik, the Alaska Eskimo Whaling Commission, and Dr. T. O'Hara and J. C. George of the North Slope Borough Department of Wildlife Management, for access to baleen plates and muscle samples. G. Sheffield of the Alaska Department of Fish \& Game undertook the recent collections of bowhead tissues at Kaktovik, and W. B. Griffiths of LGL collected the recent zooplankton samples. Laboratory analyses and sample preparation of previously collected samples were performed by K. Vinette and B. Barnett. The mass spectrometry analyses were run by N. Haubenstock and T. Howe. This study was funded by the U.S. Minerals Management Service through MMS contract 30842 awarded to LGL Ecological Research Associates Inc. and a subcontract from LGL to the University of Alaska Fairbanks. Collection of bowhead tissue specimens was done under NMFS Scientific Research Permits 797 and 481-1464 (Kaktovik) and 932-1489-90 (Barrow). We thank Dr. K. Hobson, members of the project's Scientific Review Board, and the referees for comments on previous drafts.

\section{LITERATURE CITED}

Aagaard K (1984) The Beaufort undercurrent. In: Barnes PW, Schell DM, Reimnitz E (eds) The Alaskan Beaufort Sea: ecosystems and environments. Academic Press, Orlando, FL, p 47-71

Best PB, Schell DM (1996) Stable isotopes in southern right whale (Eubalaena australis) baleen as indicators of seasonal movements, feeding and growth. Mar Biol 124:483-494

Bockstoce JR, Burns JJ (1993) Commercial whaling in the North Pacific sector. In: Burns JJ, Montague JJ, Cowles CJ (eds) The bowhead whale. Allen Press, Lawrence, KS, p 563-577

Bradstreet MSW, Thomson DH, Fissel DB (1987) Zooplankton and bowhead whale feeding in the Canadian Beaufort Sea, 1986. Chap 1. In: Bradstreet MSW, Thomson DH, Fissel DB (eds) Bowhead whale food availability characteristics in the Southern Beaufort Sea: 1985 and 1986. Environmental Studies 50. Indian and Northern Affairs Canada, Ottawa, p 1-204

Carroll GM, George JC, Lowry LF, Coyle KO (1987) Bowhead whale (Balaena mysticetus) feeding near Point Barrow, Alaska, during the 1985 spring migration. Arctic 40: 105-110

Cullen JT, Rosenthal Y, Falkowski PG (2001) The effect of anthropogenic $\mathrm{CO}_{2}$ on the carbon isotope composition of marine phytoplankton. Limnol Oceanogr 46:996-998
Fischman AJ, Yong MY, Livni E, Babich JW, Young VR, Alpert NA, Tompkins RG (1998) Muscle protein synthesis by positron emission tomography with $\mathrm{L}-\left[\right.$ methyl $-{ }^{11} \mathrm{C}$ ] methionine in adult humans. Proc Natl Acad Sci 95: 12793-12798

Fry B (1981) Natural stable carbon isotope, tag traces Texas shrimp migrations. Fish Bull US Dep Comm 79:337-345

Gannes LZ, O'Brien DM, Martínez del Rio C (1997) Stable isotopes in animal ecology: assumptions, caveats, and a call for more laboratory experiments. Ecology 78: $1271-1276$

George JC, Philo LM, Carroll GM, Albert TF (1988) 1987 subsistence harvest of bowhead whales, Balaena mysticetus, by Alaskan Eskimos. Rep Int Whal Comm 38:389-392

George JC, Zeh J, Suydam R, Clark C (2004) Abundance and population trend (1978-2001) of Western Arctic bowhead whales surveyed near Barrow, Alaska. Mar Mamm Sci 20: 755-773

Griffiths WB, Thomson DH, Bradstreet MSW (2002) Zooplankton and water masses at bowhead whale feeding locations in the Eastern Beaufort Sea. Chap 6. In: Richardson WJ, Thomson DH (eds) Bowhead whale feeding in the eastern Alaskan Beaufort Sea: update of scientific and traditional information. 2 volumes. OCS study MMS 2002012. Report from LGL Ltd, King City, Ontario, for US Minerals Management Service, Anchorage, AK. NTIS PB2004-101568. National Technical Information Service, Springfield, VA, p 6-1 to 6-44. Available at www.mms.gov/ alaska/ref/ AKPUBS.HTM\#2002

Hobson KA, Clark RG (1992) Assessing avian diets using stable isotope analysis: I. Turnover of ${ }^{13} \mathrm{C}$ in tissues. Condor 94:181-188

Hobson KA, Alisauskas RT, Clark RG (1993) Stable-nitrogen isotope enrichment in avian tissues due to fasting and nutritional stress: implications for isotopic analyses of diet. Condor 95:388-394

Hobson KA, Schell DM, Renouf D, Noseworthy E (1996) Stable carbon and nitrogen fractionation between diet and tissues of captive seals: implications for dietary reconstructions involving marine mammals. Can J Fish Aquat Sci 53:528-533

Hoekstra PF, Dehn LA, George JC, Solomon KR, Muir DCG, O'Hara TM (2002) Trophic ecology of bowhead whales (Balaena mysticetus) compared with that of other arctic marine biota as interpreted from carbon-, nitrogen-, and sulphur-isotope signatures. Can J Zool 80:223-231

Koski WR, Miller GW (2002) Habitat use by different size classes of bowhead whales in the eastern Alaskan Beaufort Sea during late summer and autumn. Chap 10. In: Richardson WJ, Thomson DH (eds) Bowhead whale feeding in the eastern Alaskan Beaufort Sea: update of scientific and traditional information. 2 volumes. OCS study MMS 2002-012. Report from LGL Ltd, King City, Ontario, for US Minerals Management Service, Anchorage, AK. NTIS PB2004-101568. National Technical Information Service, Springfield, VA, p 10-1 to 10-21. Available at www. mms.gov/alaska/ref/AKPUBS.HTM\#2002

Landino SW, Treacy SD, Zerwick SA, Dunlap JB (1994) A large aggregation of bowhead whales (Balaena mysticetus) feeding near Point Barrow, Alaska, in late October 1992. Arctic 47:232-235

Lockyer C (1981) Growth and energy budgets of large baleen whales from the southern hemisphere. FAO Fish Ser (5)III: 379-487

Lowry LF (1993) Foods and feeding ecology. In: Burns JJ, Montague JJ, Cowles CJ (eds) The bowhead whale. Allen Press, Lawrence, KS, p 201-238 
Lowry LF, Sheffield G, George JC (in press) Bowhead whale feeding in the Alaskan Beaufort Sea. J Cetacean Res Manag

Macdonald RW, Carmack EC (1991) Age of Canada Basin deep waters: a way to estimate primary production for the Arctic Ocean. Science 254:1348-1350

Macdonald RW, Wong CS, Erickson PE (1987) The distribution of nutrients in the southeastern Beaufort Sea: implications for water circulation and primary production. J Geophys Res 92:2939-2952

Macdonald RW, Solomon SM, Cranston RE, Welch HE, Yunker MB, Gobeil C (1998) A sediment and organic carbon budget for the Canadian Beaufort shelf. Mar Geol 144:255-273

McDonald TL (2002) Variance of bowhead feeding fraction based on stable isotope analysis. Appendix 20.1. In: Richardson WJ, Thomson DH (eds) Bowhead whale feeding in the eastern Alaskan Beaufort Sea: update of scientific and traditional information. 2 volumes. OCS study MMS 2002-012. Report from LGL Ltd, King City, Ontario, for US Minerals Management Service, Anchorage, AK. NTIS PB2004-101568. National Technical Information Service, Springfield, VA, p 20-25 to 20-28. Available at www.mms.gov/alaska/ref/AKPUBS. HTM\#2002

Moore SE, Reeves RR (1993) Distribution and movement. In: Burns JJ, Montague JJ, Cowles CJ (eds) The bowhead whale. Allen Press, Lawrence, KS, p 313-386

Moore SE, George JC, Coyle KO, Weingartner TJ (1995) Bowhead whales along the Chukotka coast in autumn. Arctic 48:155-160

Niebauer HJ, Schell DM (1993) Physical environment of the Bering Sea population. In Burns JJ, Montague JJ, Cowles CJ (eds) The bowhead whale. Allen Press, Lawrence, KS, p 491-506

Richardson WJ, Davis RA, Evans CR, Ljungblad DK, Norton P (1987) Summer distribution of bowhead whales, Balaena mysticetus, relative to oil industry activities in the Canadian Beaufort Sea, 1980-1984. Arctic 40:93-104

Ross WG (1993) Commercial whaling in the North Atlantic sector. In: Burns JJ, Montague JJ, Cowles CJ (eds) The bowhead whale. Allen Press, Lawrence, KS, p 511-562

Saupe SM, Schell DM, Griffiths W (1989) Carbon isotope ratio gradients in western arctic zooplankton. Mar Biol 103: $427-432$

Schell DM (1987) Bowhead whale feeding: allocation of regional habitat importance based on stable isotope abundances. In: Richardson WJ (ed) Importance of the eastern Alaska Beaufort Sea to feeding bowhead whales, 1985-86. Report by LGL Ecological Research Associates, Inc., for US Minerals Management Service, Anchorage, AK. NTIS PB88-150271/AF. National Technical Information Service, Springfield, VA, p 369-415

Schell DM (1992) Stable isotope analysis of 1987-1991 zooplankton samples and bowhead whale tissues. OCS Study MMS 92-0020. Rep. from Univ. Alaska, Fairbanks, AK,

Editorial responsibility: Otto Kinne (Editor-in-Chief), Oldendorf/Luhe, Germany
US Minerals Management Service, Anchorage, AK, NTIS PB93-135879, National Technical Information Service, Springfield, VA

Schell DM (2000) Declining carrying capacity in the Bering Sea: isotopic evidence from whale baleen. Limnol Oceanogr 45:459-462

Schell DM (2001) Carbon isotope ratio variations in Bering Sea biota: the role of anthropogenic carbon dioxide. Limnol Oceanogr 46:999-1000

Schell DM, Saupe SM (1993) Feeding and growth as indicated by stable isotopes. In: Burns JJ, Montague JJ, Cowles CJ (eds) The bowhead whale. Allen Press, Lawrence, KS, p 491-509

Schell DM, Saupe SM, Haubenstock N (1989) Bowhead growth and feeding as indicated by $\delta^{13} \mathrm{C}$ techniques. Mar Biol 103:433-443

Schell DM, Barnett BA, Vinette K (1998) Carbon and nitrogen isotope ratios in zooplankton of the Bering, Chukchi and Beaufort Seas. Mar Ecol Prog Ser 162:11-23

Springer AM, McRoy CP, Turco KR (1989) The paradox of the pelagic food webs in the northern Bering Sea. II. Zooplankton communities. Contin Shelf Res 9:359-386

Springer AM, McRoy CP, Flint MV (1996) The Bering Sea green belt: shelf edge processes and ecosystem production. Fish Oceanogr 5:205-223

Stoker SW, Krupnik II (1993) Subsistence whaling. In: Burns JJ, Montague JJ, Cowles CJ (eds) The bowhead whale. Allen Press, Lawrence, KS, p 579-629

Treacy SD (2002) Aerial surveys of endangered whales in the Beaufort Sea, fall 2001 OCS Study MMS 2002-061, US Minerals Management Service, Anchorage, AK

Víkingsson GA (1990) Energetic studies on fin and sei whales caught off Iceland. Rep Int Whal Comm 40:365-373

Würsig B, Clark C (1993) Behavior. In: Burns JJ, Montague JJ, Cowles CJ (eds) The bowhead whale. Allen Press, Lawrence, KS, p 157-199

Würsig B, Dorsey EM, Fraker MA, Payne RS, Richardson WJ (1985) Behavior of bowhead whales, Balaena mysticetus, summering in the Beaufort Sea: a description. Fish Bull US Dep Comm 83:357-377

Würsig B, Dorsey EM, Richardson WJ, Wells RS (1989) Feeding, aerial and play behaviour of the bowhead whale, Balaena mysticetus, summering in the Beaufort Sea. Aquat Mamm 15:27-37

Würsig B, Koski WR, Thomas TA, Richardson WJ (2002) Activities and behavior of bowhead whales in the eastern Alaskan Beaufort Sea during late summer and autumn. Chap 12. In: Richardson WJ, Thomson DH (eds) Bowhead whale feeding in the eastern Alaskan Beaufort Sea: update of scientific and traditional information. 2 volumes. OCS study MMS 2002-012. Report from LGL Ltd, King City, Ontario, for US Minerals Management Service, Anchorage, AK. NTIS PB2004-101568. National Techn-ical Information Service, Springfield, VA, p 12-1 to 12-38. Available at www.mms.gov/alaska/ref/AKPUBS. HTM\#2002

Submitted: November 19, 2003; Accepted: August 12, 2004

Proofs received from author(s): December 22, 2004 